\title{
Lipemia poposiłkowa - problem kliniczny i potencjalne miejsce $w$ algorytmach diagnostycznych Stanowisko polskich ekspertów
}

\author{
Postprandial lipemia: a clinical problem and potential place \\ in cardiovascular risk estimation. The position of Polish experts
}

\author{
Anna Skoczyńska ${ }^{1}$ (D), Marta Wawrzynowicz-Syczewska ${ }^{2}$ (D), \\ Marta Barlik-Rysa ${ }^{3,4}$ (D), Andrzej Danik ${ }^{5}$, Jacek Różański ${ }^{6}$ (D), \\ Krzysztof J. Filipiak ${ }^{7}$ (i), Barbara Cybulska ${ }^{8}$ (iD
}

\footnotetext{
${ }^{1}$ Katedra i Klinika Chorób Wewnętrznych, Zawodowych i Nadciśnienia Tętniczego Uniwersytetu Medycznego we Wrocławiu

${ }^{2}$ Klinika Chorób Zakaźnych, Hepatologii i Transplantacji Wątroby Pomorskiego Uniwersytetu Medycznego w Szczecinie

${ }^{3}$ Poradnia Endokrynologii i Zaburzeń Metabolicznych Centrum Medycznego w Gliwicach

${ }^{4}$ Fundacja Rozwoju Kardiochirurgii im. prof. Zbigniewa Religi w Zabrzu

${ }^{5}$ Oddział Chirurgii Naczyniowej i Endowaskularnej Śląskiego Centrum Chorób Serca w Zabrzu

${ }^{6}$ Klinika Nefrologii, Transplantologii i Chorób Wewnętrznych Pomorskiego Uniwersytetu Medycznego w Szczecinie

${ }^{7}$ K Katedra i Klinika Kardiologii Warszawskiego Uniwersytetu Medycznego

${ }^{8}$ Narodowy Instytut Zdrowia Publicznego - Państwowy Zakład Higieny
}

\section{Streszczenie}

W poniższym opracowaniu przedstawiono stanowiska ekspertów z różnych towarzystw, głównie europejskich, dotyczące roli hipertriglicerydemii (HTG) poposiłkowej w przewidywaniu ryzyka sercowo-naczyniowego (CV). Uwzględniono nowe badania i różne kategorie pacjentów. Oparto się głównie na wytycznych European Society of Cardiology i European Atherosclerosis Society z 2019 roku, dotyczących postępowania w dyslipidemii, oraz panelu Postprandial hypertriglyceridaemia revisited in era of non-fasting lipid profile testing: a 2019 Expert Panel Statement, main text. Przedstawiono także stanowisko polskich ekspertów stosujących doustny test tolerancji tłuszczów w praktyce klinicznej. Problemem pozostaje ocena roli HTG w szacowaniu ryzyka CV oraz ustalenie, czy spożycie standardowego wysokotłuszczowego preparatu, a następnie pobranie krwi we wskazanym przedziale czasowym, czyli doustny test tolerancji tłuszczów, może poprawić ocenę ryzyka CV. Znaczenie HTG poposiłkowej w ocenie ryzyka aterogennego jest coraz lepiej udokumentowane, jakkolwiek istnieje potrzeba dalszych badań.

Słowa kluczowe: hipertriglicerydemia, ryzyko sercowo-naczyniowe, doustny test tolerancji tłuszczów (OFTT)

Folia Cardiologica 2020; 15, supl. A: A1-A17

Adres do korespondencji: prof. dr hab. n. med. Anna Skoczyńska, Katedra i Klinika Chorób Wewnętrznych, Zawodowych i Nadciśnienia Tętniczego, Uniwersytet Medyczny we Wrocławiu, ul. Borowska 213, 50-556 Wrocław, e-mail: anna.skoczynska@umed.wroc.pl 
Wytyczne ESC/EAS 2019 dotyczące

postępowania $\mathrm{w}$ dyslipidemii: modyfikacja lipidów w celu obniżenia ryzyka sercowo-naczyniowego

Zgodnie z wytycznymi towarzystw europejskich - Europejskiego Towarzystwa Kardioloicznego (ESC, European Society of Cardiology) i Europejskiego Towarzystwa Badań nad Miażdżycą (EAS, European Atherosclerosis Society) z 2019 roku [1] oraz zgodnie ze stanowiskiem panelu ekspertów zatytułowanym Postprandial hypertriglyceridaemia revisited in era of non-fasting lipid profile testing: a 2019 Expert Panel Statement, main text [2] głównym sposobem zmniejszenia ryzyka sercowo-naczyniowego (CV, cardiovascular) jest obniżenie stężenia cholesterolu zawartego w lipoproteinach o małej gęstości (LDL-C, low-density lipoprotein cholesterol). Zalecenie to oparto na wnioskach wynikających z badań podstawowych, obserwacji klinicznych, badań epidemiologicznych, w tym przeprowadzonych metodą randomizacji Mendla, i z randomizowanych prób klinicznych. Szczególną uwage zwrócono na wyniki metaanaliz potwierdzających zmniejszenie ryzyka CV zależne od redukcji stężenia LDL-C; im większa była bezwzględna redukcja stężenia LDL-C, tym większe było zmniejszenie ryzyka CV [3-5]. Nie zdefiniowano jednak wartości LDL-C, poniżej którego ustaje korzyść lub pojawia się efekt szkodliwy dalszego obniżania stężenia LDL-C.

Ryzyko wystąpienia epizodów CV jest różne u poszczególnych osób i zależy od tego, czy dana osoba przebyła już w życiu taki epizod(y), czy ma miażdżycę tętnic wieńcowych i/lub obwodowych, czy choruje na cukrzycę lub przewlekłą chorobę nerek (CKD, chronic kidney disease), czy jest obciążona tak zwanymi czynnikami ryzyka (jakie, ile i w jakim nasileniu), czy też nie. Dlatego ustalono cztery kategorie ryzyka i odpowiednie dla nich cele terapeutyczne dla LDL-C.

\section{Całkowite ryzyko sercowo-naczyniowe}

Zapobieganie chorobom układu sercowo-naczyniowego na tle miażdżycy (ASCVD, atherosclerotic cardiovascular disease) powinno się odnosić do indywidualnie oszacowanego całkowitego ryzyka CV: im wyższe ryzyko, tym bardziej intensywne powinno być działanie.

Ryzyko CV w kontekście wytycznych ESC i EAS oraz innych wytycznych oznacza prawdopodobieństwo wystąpienia zdarzenia CV na tle miażdżycy w określonym przedziale czasu. Całkowite ryzyko CVD wyraża łączny wpływ wielu czynników na to prawdopodobieństwo. Szczególną uwage zwraca się na udział lipidów w całkowitym ryzyku CV i sposoby postępowania na poziomie klinicznym.

Dostępnych jest wiele systemów oceny ryzyka. Idealnie, wykresy ryzyka powinny opierać się na danych kohortowych dla danego kraju. Europejskie wytyczne dotyczące zapobiegania CVD w praktyce klinicznej zalecają stosowanie systemu SCORE (Systematic COronary Risk Evaluation), ponieważ jest on oparty na dużych, reprezentatywnych danych z badań kohorty europejskiej, a ponowna kalibracja dla poszczególnych krajów jest stosunkowo łatwa. Osoby z udokumentowaną ASCVD, cukrzycą typu 1 (T1DM, type 1 diabetes mellitus) lub typu 2 (T2DM, type 2 diabetes mellitus), obciążone bardzo wysokim poziomem poszczególnych czynników ryzyka lub CKD są ogólnie narażone na bardzo wysokie lub wysokie całkowite ryzyko CV. Dla takich osób nie są potrzebne modele szacowania ryzyka; wszyscy potrzebują aktywnej redukcji modyfikowalnych czynników ryzyka. U innych, nawet pozornie zdrowych, osób zaleca się stosowanie systemu oceny ryzyka, takiego jak SCORE, za pomocą którego szacuje się 10-letnie skumulowane ryzyko śmiertelnego zdarzenia miażdżycowego. U wielu osób występuje kilka czynników ryzyka, które w połączeniu mogą kwalifikować do kategorii wysokiego ryzyka. Uaktualniona wersja oceny ryzyka CV dla populacji polskiej Pol-SCORE jest dostępna na stronach internetowych (np. http://www. heartscore.org).

\section{Obniżenie stężenia LDL-C jako główny cel prewencji ASCVD}

Obniżenie stężenia LDL-C jest kluczowym, opartym na dowodach, podejściem do zapobiegania epizodom CV na tle miażdżycy [6-10]. Istnieją dowody wskazujące na to, że obniżenie stężenia LDL-C znacznie poniżej celów określonych w poprzednich wytycznych EAS/ESC (z 2016 r.) wiąże się z mniejszą liczbą zdarzeń CV [11-13]. Wydaje się więc właściwe obniżenie stężenia LDL-C do możliwie najniższego poziomu, przynajmniej u pacjentów obciążonych bardzo wysokim ryzykiem CV. Podstawą wytyczenia takiego nowego celu leczenia hipolipemizującego w wytycznych ESC/EAS z roku 2019 są obserwacje dotyczące zmniejszenia ryzyka epizodów CV na tle miażdżycy poprzez bardzo znaczne obniżenie stężenia LDL-C do poziomów osiągniętych dzięki zastosowaniu inhibitorów proproteinowej subtilizyny/ /kexiny 9 (PCSK-9, proprotein convertase subtilisin/kexin type 9). Dlatego u pacjentów obciążonych bardzo wysokim ryzykiem CV, zarówno w profilaktyce wtórnej, jak i (rzadko) w profilaktyce pierwotnej, zaleca się obniżenie stężenia LDL-C o co najmniej 50\% w stosunku do wartości wyjściowej i docelową wartość LDL-C poniżej 1,4 mmol/l (<55 mg/dl). U pacjentów z ASCVD, którzy doświadczyli drugiego zdarzenia naczyniowego w ciągu 2 lat (niekoniecznie tego samego typu co pierwsze zdarzenie), należy rozważyć redukcję stężenia LDL-C do wartości poniżej $1 \mathrm{mmol} / \mathrm{l}(<40 \mathrm{mg} / \mathrm{dl})$ poprzez zastosowanie maksymalnej tolerowanej dawki silnej statyny, a u osób obciążonych wysokim ryzykiem CV zaleca się obniżenie stężenia LDL-C o co najmniej 50\% w stosunku do wartości wyjściowej i docelowe stężenie LDL-C poniżej 1,8 mmol/l (< $70 \mathrm{mg} / \mathrm{dl}$ ). U pacjentów cechujących się umiarkowanym ryzykiem CV należy wziąć pod 
uwagę osiągnięcie celu LDL-C poniżej 2,6 mmol/l $(<100$ $\mathrm{mg} / \mathrm{dl})$, natomiast w przypadku osób cechujących niskim ryzykiem można rozważyć cel LDL-C poniżej 3,0 mmol/l (< $116 \mathrm{mg} / \mathrm{dl})[14,15]$.

\section{Ryzyko resztkowe ASCVD}

Nawet intensywne obniżenie stężenia LDL-C za pomocą statyn (z innymi lekami lub bez nich) nie znosi tak zwanego ryzyka resztkowego ASCVD [14, 16-19]. Przyczyną tego ryzyka może być podwyższone stężenie lipoprotein bogatych w triglicerydy (TG, triglycerides) [20-23]. Inne, pozalipidowe czynniki ryzyka, w tym: palenie tytoniu, cukrzyca, nadciśnienie tętnicze, autoimmunologiczne choroby układowe, zaburzona czynność nerek, predyspozycje genetyczne i uwarunkowania epigenetyczne, mogą się przyczyniać do utrzymywania się resztkowego ryzyka ASCVD. Także niedostateczne, w odniesieniu do określonego poziomu ryzyka ASCVD, obniżenie stężenia LDL-C i/lub nieodpowiednia korekta innych zmiennych lipidowych i pozalipidowych czynników ryzyka może wpływać na występowanie ryzyka rezydualnego. Wśród zmiennych lipidowych istotne znaczenie mają zwiększone stężenie TG i bogatych w TG resztkowych lipoprotein w osoczu. W badaniu BIP (Bezafibrate Infarction Prevention), obejmującym pacjentów z rozpoznaniem choroby niedokrwiennej serca (CHD, coronary heart disease), wykazano, że wyższe stężenia TG są niezależnie związane ze zwiększoną 22-letnią śmiertelnością, nawet u pacjentów z TG w zakresie 1,2-1,7 mmol/l (106-150 mg/dl) [24]. W próbie TNT (Treating to New Targets), po osiągnięciu docelowej wartości LDL-C w zakresie 1,8-2,6 mmol/I (70-100 mg/dl), ryzyko CV było znacznie zmniejszone; jednak u 9\% uczestników otrzymujących atorwastatynę w dawce $80 \mathrm{mg}$ nadal dochodziło do poważnego zdarzenia CV w ciągu ponad 5-letniej obserwacji [25]. Analiza post hoc badania TNT dowiodła, że wyższe stężenia cholesterolu lipoprotein bogatych w TG wiązały się z większą częstością zdarzeń CV w 5-letniej obserwacji. Analiza ta dostarczyła także dowodów wskazujących na korzyści wynikające z działania hipolipemizującego statyny u pacjentów z CHD i wysokim stężeniem cholesterolu lipoprotein bogatych w TG [26]. U pacjentów z wyższym stężeniem cholesterolu lipoprotein bogatych w TG bardziej intensywna terapia atorwastatyną w dawce $80 \mathrm{mg}$, w porównaniu z atorwastatyną w dawce $10 \mathrm{mg}$, powodowała większe obniżenie ryzyka CV [26]. Wyniki te były zgodne z wynikami obserwacji zwiększonego ryzyka CV skojarzonego z podwyższonymi wartościami TG w połączonych kohortach badań TNT i IDEAL (Incremental Decrease in End Point through Aggressive Lipid Lowering) [27]. Ponadto w badaniu JUPITER (Justification for the Use of Statins in Prevention: An Intervention Trial Evaluating Rosuvastatin) wykazano, że w warunkach na czczo stężenia średnich i małych czasteczek lipoprotein o bardzo małej gęstości (VLDL, very-low-density lipoproteins) i dużych cząsteczek LDL wiązały się ze zwiększonym resztkowym ryzykiem CVD u pacjentów przyjmujących statynę. Wskazuje to na istotny wpływ cząsteczek resztkowych na ryzyko ASCVD, nawet podczas terapii statyną [28].

\section{Apolipoproteina B (ApoB)}

Z wyjątkiem cząsteczek lipoprotein o dużej gęstości (HDL, high-density lipoproteins) wszystkie inne lipoproteiny zawierają apolipoproteinę B (ApoB-48 lub ApoB-100) jako główną Apo strukturalną. Zarówno VLDL, jak i ich remnanty zawierają głównie ApoB-100, a chylomikrony i ich pozostałości - Apo B-48. Jakkolwiek remnanty oraz ich macierzyste chylomikrony i VLDL są zwykle określane mianem lipoprotein bogatych w TG, są one także bogate w cholesterol, dlatego bywaja nazywane lipoproteinami/ /remnantami bogatymi w TG i bogatymi w cholesterol lub po prostu jako resztkowy cholesterol [29-36]. Pomiar wskaźników, takich jak całkowite ApoB i nie-HDL-C, resztkowy cholesterol (obliczany jako cholesterol całkowity [TC, total cholesterol] - LDL-C - HDL-C) u osób będących na czczo lub nie na czczo odzwierciedla zatem szersze spektrum aterogennych lipoprotein niż same LDL [37] i jest szczególnie wskazany u osób z hipertriglicerydemią, cukrzycą, otyłością i zespołem metabolicznym [1].

Nośnikami większości krążących TG w osoczu na czczo są bogate w apoB cząsteczki VLDL i ich resztki (remnanty). Stężenie TG w osoczu odzwierciedla więc stężenie krążących lipoprotein bogatych w TG zawierających ApoB. Podwyższone stężenie TG w osoczu wiąże się ze wzrostem ryzyka ASCVD, ale związek ten staje się zerowy po skorygowaniu o wartość nie-HDL-C, czyli całkowite stężenie wszystkich lipoprotein zawierających ApoB [38]. Podobnie obniżenie stężenia TG za pomocą fibratów zmniejsza ryzyko zdarzeń CV w takim samym stopniu jak terapia obniżająca wartości LDL-C, kiedy oba sposoby leczenia są oceniane w przeliczeniu na jednostkową zmianę stężenie nie-HDL-C [39]. Sugeruje to, że w oddziaływaniu osoczowych TG na ryzyko ASCVD pośredniczą zmiany w stężeniu lipoprotein bogatych w TG.

W badaniach metodą randomizacji Mendla wykazano, że związek między TG w osoczu a ryzykiem CHD może być przyczynowy. Wyniki te należy interpretować ostrożnie, ponieważ prawie wszystkie warianty genetyczne związane z TG są również związane z HDL-C, LDL-C lub lipoproteiną(a) [Lp(a)] [40-42]. Ostatnio wykazano, że lipaza lipoproteinowa (LPL, lipoprotein lipase) obniżająca TG (warianty LPL) i warianty receptora LDL obniżające LDL miały taki sam wpływ na ryzyko CHD w odniesieniu do jednostkowej zmiany ApoB, co sugeruje, że wszystkie lipoproteiny zawierające ApoB podobnie wpływają na ryzyko CV [43]. Łącznie badania te wskazują, że związek przyczynowo-skutkowy między lipoproteinami (remnantami) bogatymi w TG i ryzykiem CV zależy od stężenia krążących cząsteczek zawierających ApoB, a nie od samej zawartości TG. 


\section{Triglicerydy na czczo i po posiłku} - lipemia poposiłkowa

Profil lipidowy, w tym wartości LDL-C i TG, mogą odzwierciedlać stan na czczo, zwykle definiowany jako 8-14 godzin od ostatniego posiłku [44, 45]. Jednak większość osób pozostaje na czczo tylko przez kilka godzin, wczesnym rankiem, przed śniadaniem. Znaczenie podwyższonych poposiłkowych stężeń lipoprotein bogatych w TG mogło nie być odpowiednio doceniane w przeszłości [7, 37]. Obecnie losowe pobieranie krwi (niezależnie od czasu od ostatniego posiłku) zaleca się w Danii, Wielkiej Brytanii, Europie, Kanadzie, Brazylii i Stanach Zjednoczonych, także rekomendują je ESC i EAS [29, 37, 46-53].

0 ile w aktualnych wytycznych ESC/EAS nie poświęca się należytej uwagi zagadnieniu czasu oznaczenia lipidogramu, o tyle wartość oznaczonego stężenia LDL-C, na przykład w ostrych zespołach wieńcowych, nie ma w świetle wytycznych żadnych uwarunkowań związanych z czasem od spożytego posiłku, stwierdzenia takiego nie można ekstrapolować na oznaczanie stężenia TG.

Hipertriglicerydemię (HTG, hypertriglyceridemia) poposiłkową uważa się za potencjalny czynnik ryzyka ASCVD [4, 54-56]. Nadprodukcja i zmniejszony katabolizm resztkowych lipoprotein bogatych w TG to dwa główne mechanizmy prowadzące do poposiłkowych nieprawidłowości lipidowych i lipoproteinowych. Z jednej strony, bogate w TG resztkowe lipoproteiny tworzą spektrum od większych do mniejszych cząsteczek, z których niektóre są prawie tak małe jak LDL, choć większość remnantów jest większa i ma mniejszą zdolność do przechodzenia do przestrzeni podśródbłonkowej niż mniejsze cząsteczki LDL [57-62]. Z drugiej strony, każda bogata w TG resztkowa lipoproteina jest 5-20 razy bogatsza w cholesterol niż każda cząsteczka LDL [61]. Prawdopodobnie z powodu większego rozmiaru w porównaniu z LDL, kiedy już przeniknie pod błonę wewnętrzną w ścianie naczyń, jest tam utrzymywana dłużej niż mniejsza cząsteczka LDL $[58,59]$. Retencja resztkowych lipoprotein bogatych w TG (i cholesterol) w błonie wewnętrznej tętnic w stanie poposiłkowym może sprzyjać rozwojowi miażdżycy (dzięki zawartości cholesterolu) [55].

Większość osób naprawdę na czczo pozostaje przez kilka godzin każdego dnia (we wczesnych godzinach porannych). Profil lipidów/lipoprotein w osoczu nie na czczo lub po posiłku lepiej odzwierciedla indywidualny zintegrowany stan metaboliczny niż profil na czczo [37, 47]. Wcześniej, w większości przypadków, podstawą oceny ryzyka CV i decyzji terapeutycznych były stężenia lipidów na czczo [45]. Nordestgaard i wsp. [37] wykazali jednak, że maksymalne średnie zmiany stężeń TC i LDL-C po 1-6 godzinach od posiłku wynosiły jedynie około 0,2 mmol/l ( $8 \mathrm{mg} / \mathrm{dl}$ ). W Copenhagen General Population Study, w populacji obejmującej 92285 mężczyzn i kobiet, stężenie TG w osoczu wykazywało nieco większe, ale wciąż niewielkie zmiany (do 0,3 mmol/l, czyli $27 \mathrm{mg} / \mathrm{dl}$ ) w czasie 1-6 godzin po ostatnim posiłku. Maksymalne średnie zmiany cholesterolu w lipoproteinach resztkowych (TC na czczo - LDL-C - HDL-C) i nie-HDL-C wyniosły, odpowiednio, 0,2 mmol/l (7,7 mg/dl) i 0,2 mmol/l $(7,7 \mathrm{mg} / \mathrm{dl})$. Maksymalne średnie zmiany stężeń lipidów i lipoprotein 1-6 godzin po regularnych posiłkach w ciągu dnia nie były więc istotne klinicznie. Jednak w populacji z hiperlipidemią odpowiedź poposiłkowa może być znacznie większa i utrzymywać się dłużej, odzwierciedlając nagromadzenie lipoprotein resztkowych w krążeniu [63-65]. W badaniu Women's Health Study dowiedziono, że stężenia TG w warunkach nie na czczo były związane z incydentami CV, niezależnie od tradycyjnych czynników ryzyka CV, stężeń innych lipidów i markerów insulinooporności; przeciwnie, stężenia TG na czczo wykazywały niewielki niezależny związek z ASCVD [66].

W badaniu Norwegian Counties stwierdzono związek między stężeniami TG nie na czczo a ryzykiem zgonu z powodu ASCVD u kobiet, ale po adiustacji względem czynników ryzyka innych niż HDL-C [67].

W badaniach FIELD (Fenofibrate Intervention and Event Lowering in Diabetes) [68] oraz ACCORD (Action to Control Cardiovascular Risk in Diabetes) [69] nie wykazano związku między terapią fibratem a występowaniem incydentów CV. W przedłużonym badaniu ACCORD (+ 5 lat obserwacji w badaniu ACCORDION) tylko 4,3\% pacjentów kontynuowało leczenie fenofibratem. Niższy odsetek zdarzeń CV w porównaniu z przyjmującymi placebo obserwowano u pacjentów z dyslipidemią, definiowaną jako HTG i niskie stężenie HDL-C [70, 71]. Podobne wyniki uzyskano w analizach podgrup w badaniach FIELD [72], HHS (Helsinki Heart Study) [71], badaniu BIP [73] i badaniu interwencyjnym VA-HDL (VAHIT [Veterans Affairs High-Density Lipoprotein Cholesterol Intervention Trial]) [74]. W powyższych badaniach potwierdzono, że osoby w podgrupach z HTG najprawdopodobniej skorzystałyby na terapii fibratem. Wykazano także, że obniżenie stężenia TG u osób z HTG przez klofibrat i kwas nikotynowy [68], gemfibrozil [74, 75], bezafibrat [57], fenofibrat [55] lub fenofibrat z simwastatyną [73] prowadzi do obniżenia ryzyka ASCVD.

Znaczenie podwyższonej lipemii poposiłkowej w rozwoju CVD także było przedmiotem badań [53]. W większości przypadków czynniki ryzyka rozwoju ASCVD pojawiają się wiele lat przed manifestacją kliniczną miażdżycy. Poposiłkową HTG oceniano w różnych populacjach w szerokim zakresie chorób (DM, zespół metaboliczny, otyłość, ASCVD i in.) przy użyciu różnych doustnych testów tolerancji tłuszczów (OFTT, oral fat tolerance test) [22, 54, 55, 66, 76, 77]. Wyniki badań epidemiolgicznych wskazują na potrzebę dalszych badań roli poposiłkowych lipoprotein bogatych w TG jako predyktorów ASCVD, tym bardziej że także wiele badań doświadczalnych $[59,60,78]$ i prób klinicznych $[25,76,77]$ wskazuje na występowanie związku między HTG i miażdżycą. 
Praktyczne trudności, jakie utrudniają badanie OFTT w praktyce, to potrzeba przygotowania posiłku testowego w celu oceny poposiłkowej HTG, pobranie kilku próbek krwi i brak ujednoliconych protokołów klinicznych. Ponadto, na szczeblu międzynarodowym, obecnie nie ma uzgodnionych wytycznych postępowania w przypadku poposiłkowej hiperlipemii.

\section{Metabolizm TG w warunkach na czczo i po posiłku}

Wzrost stężenia TG w osoczu w ciągu 10-30 minut od spożycia posiłku zawierającego tłuszcze wynika ze spożycia wcześniejszych posiłków (pochodzi z puli TG przechowywanych w enterocytach) oraz pochodzi z sekrecji chylomikronów, związanej ze stymulacją jamy ustnej przez przyjmowany pokarm [79]. Krążące w osoczu TG obserwowane przez kilka godzin po posiłku pochodzą z chylomikronów syntetyzowanych w jelitach i zawierających spożyte tłuszcze oraz z VLDL pochodzących z wątroby (zależy to od dostępności cholesterolu wątrobowego, który kontroluje ekspresję receptorów LDL). Triglicerydy obecne w osoczu na czczo w prawidłowych warunkach znajdują się w VLDL i mają pochodzenie wątrobowe (z zasobów kwasów tłuszczowych i puli wątrobowej TG kontrolowanych przez insulinę wytwarzanych przez całą dobę) [80]. Natomiast około 80\% wzrostu stężenia TG po posiłku tłuszczowym pochodzi z chyIomikronów, około 80\% wzrostu liczby cząsteczek przypada na cząsteczki VLDL [81]. W stanie poposiłkowym do wątroby „dochodzą" więc zwiększone ilości kwasów tłuszczowych oraz węglowodanów pochodzące z diety. W wątrobie przyjmowane w posiłku kwasy tłuszczowe są reestryfikowane do TG [82], a węglowodany mogą być przekształcane w TG (lipogeneza de novo). W stanie na czczo u zdrowych osób wkład lipogenezy de novo w wątrobie do puli TG wynosi mniej niż 5\% (dla VLDL), ale po posiłkach zwiększa się do $23 \%[83,84]$.

\section{Aktualne wytyczne dotyczące} triglicerydemii na czczo i po posiłku

Do niedawna w większości wytycznych koncentrowano się wyłącznie na leczeniu ciężkiej HTG: TG ponad $500 \mathrm{mg} / \mathrm{dl}$ (5,6 mmol/l), ponad $885 \mathrm{mg} / \mathrm{dl}(10 \mathrm{mmol} / \mathrm{l})$ lub powyżej $1000 \mathrm{mg} / \mathrm{dl}$ (11,3 mmol/l) w celu obniżenia ryzyka ostrego zapalenia trzustki $[50,53,85]$. Podejście to zmieniło się po opublikowaniu wyników takich badań, jak Copenhagen City Heart Study [29, 49], Women's Health Study [66] i Copenhagen General Population Study [22, 23].

W panelu EAS opublikowanym w 2014 roku oraz wspólnym stanowisku EAS i Europejskiej Federacji Chemii Klinicznej i Medycyny Laboratoryjnej (EFLM, European Federation of Clinical Chemistry and Laboratory Medicine) z 2016 roku przyjęto, że profil lipidowy nie na czczo jest nie tylko wygodny, ale także równoważny lub nawet bardziej przydatny w prognozowaniu ryzyka ASCVD niż profil na czczo [37]. Podobne stanowisko zawarto w wytycznych United Kingdom National Institute for Health and Care Excellence (UK NICE) w 2014 roku [7] oraz Veterans Affairs and US Department of Defense [86]. Zgodnie z panelem National Lipid Association (NLA) podwyższone wartości TG po posiłku są związane z niższymi stężeniami HDL-C, wzrostem stężenia małych gęstych cząsteczek LDL (sdLDL, small dense LDL), upośledzoną funkcją śródbłonka i mogą przyspieszyć tworzenie się blaszki miażdżycowej [87]. Według wytycznych Canadian Hypertension Education Program [51] i Canadian Cardiovascular Society [8] profil lipidów oznaczany nie na czczo jest akceptowalny u pacjentów z nadciśnieniem tętniczym.

Według wytycznych ESC/EAS z 2016 roku do badań przesiewowych i oceny ryzyka CV można wykorzystywać stężenia TG nie na czczo [50]. Podkreślono, że dyslipidemia w zespole metabolicznym stanowi grupę nieprawidłowości lipidowych i lipoproteinowych, w tym podwyższenie stężenia TG na czczo i po posiłku, ApoB i sdLDL, a także obniżone stężenia HDL-C i ApoAl.

W wytycznych Amerykańskiego Towarzystwa Endokrynologów Klinicznych (AACE, American Association of Clinical Endocrinologists) podkreślono, że podwojenie częstości występowania otyłości spowodowało wzrost stężeń TG o 33\% w populacji ogólnej. Jednocześnie sklasyfikowano nie-HDL-C jako główny czynnik ryzyka CV (nie-HDL transportujące TG zawierają także aterogenny cholesterol), a HTG na czczo i po posiłku oraz podwyższone stężenie apoB jako dodatkowe czynniki ryzyka [88].

Zgodnie z zaleceniami American College of Cardiology/ /American Heart Association Task Force on Clinical Practice Guidelines u dorosłych w wieku co najmniej 20 lat występowanie umiarkowanej HTG na czczo lub nie na czczo (TG 1,9-5,6 mmol/l, czyli 168-499 mg/dl) jest wskazaniem do wdrożenia leczenia, uwzględniającego czynniki związane ze stylem życia (otyłość i zespół metaboliczny), obecność takich chorób, jak cukrzyca, przewlekła choroba wątroby lub CKD i/lub zespół nerczycowy, niedoczynność tarczycy, a także stosowanie leków zwiększających stężenie TG. U dorosłych w wieku 40-75 lat z utrzymującą się umiarkowaną lub ciężką HTG na czczo większą lub równą $5,6 \mathrm{mmol} / \mathrm{l}$ (> $500 \mathrm{mg} / \mathrm{dl}$ ) i obciążonych ryzykiem ASCVD $7,5 \%$ lub wyższym, uzasadnione jest rozważenie rozpoczęcia lub intensyfikacji leczenia statyną [89].

Zalecenia ESC/EAS z 2019 roku dotyczące decyzji farmakologicznych u pacjentów z HTG przedstawiono $w$ tabeli 1 [26, 90-94]).

\section{Genetyczne uwarunkowania HTG}

Choć etiologia genetyczna HTG wydaje się bardzo złożona, to ostatnie dane poszerzyły rozumienie HTG uwarunkowanej 
Tabela 1. Zalecenia dotyczące farmakoterapii u pacjentów z hipertriglicerydemią (HTG, hypertriglyceridemia) (źródła [26, 90-94])

U osób z HTG (TG > 2,3 mmol/l, czyli > $200 \mathrm{mg} / \mathrm{dl}$ ) i obarczonych wysokim ryzykiem CVD lekiem pierwszego rzutu w celu obniżenia ryzyka CVD jest statyna (klasa zaleceń I, poziom wiarygodności danych B) [26]

U pacjentów z grupy wysokiego (lub bardzo wysokiego) ryzyka ze stężeniem TG między 1,5 a 5,6 mmol/l, czyli 135-499 mg/dl, poza leczeniem statyną powinno się rozważyć n-3 PUFA (kwas eikozapentaenowy) w dawce $2 \times 2 \mathrm{~g} / \mathrm{d}$. w kombinacji ze statyną (klasa zaleceń IIA, poziom wiarygodności danych B) [90]

W profilaktyce pierwotnej pacjentów, którzy osiągnęli docelowe stężenie LDL-C, z TG > 2,3 mmol/l, czyli > $200 \mathrm{mg} / \mathrm{dl}$, można rozważyć fenofibrat lub bezafibrat w kombinacji ze statyną (klasa zaleceń Ilb, poziom wiarygodności danych B) [91-94]

U pacjentów z grupy wysokiego ryzyka, którzy osiągnęli docelowe stężenie LDL-C, z TG > 2,3 mmol/L, czyli > $200 \mathrm{mg} / \mathrm{dl}$, można rozważyć fenofibrat lub bezafibrat w kombinacji ze statyną (klasa zaleceń Ilb, poziom wiarygodności danych C) [91-94]

TG (triglycerides) - triglicerydy; CVD (cardiovascular diseases) - choroby układu sercowo-naczyniowego; n-3 PUFA ( $n$-3 polyunsaturated fatty acids) - wielonienasycone kwasy tuszczowe n-3; LDL-C (low-density lipoprotein cholesterol) - cholesterol lipoprotein o małej gęstości

genetycznie, szczególnie chylomikronemii [95]. Umiarkowane podwyższenie stężenia TG (między 2,0 a $10,0 \mathrm{mmol} / \mathrm{I}$ ) jest spowodowane poligenowym działaniem genów wpływających zarówno na wytwarzanie, jak i usuwanie VLDL. Monogenowa ciężka HTG powoduje chylomikronemię, złogi lipidów w tkance otaczającej trzustkę i w samym miąższu trzustki oraz zapalenie trzustki. Do tej pory uznano, że monogenowe mutacje w sześciu genach $(L P L$, apoC2, apoA5, LMF1, GPIHBP1 i GPD1) prowadzą do ciężkiego podwyższenia TG w surowicy z powodu zaburzeń katabolizmu chylomikronów. Mutacje te są dziedziczone jako cechy autosomalne recesywne i występują rzadko. Głęboka wada w katabolizmie chylomikronów i VLDL powoduje chylomikronemię i stężenia TG ponad 11,2 mmol/l (> $1000 \mathrm{mg} / \mathrm{dl}$ ), z mętną i mleczną surowicą. Ciężką HTG obserwuje się u pacjentów homozygotycznych, u których występuje mutacja genu enzymu LPL oraz innych genów związanych z katabolizmem lipoprotein bogatych w TG.

$U$ heterozygotycznych nosicieli tych samych mutacji genowych stężenia TG w surowicy często są umiarkowanie podwyższone, co może zwiększać ryzyko CVD [96]. W ostatnim okresie opracowano i przetestowano terapię genową niedoboru LPL w badaniach klinicznych [97], jednak terapia ta jest niedostępna. Mutacja genu apolipoproteiny 3 prowadząca do jej zwiększonego stężenia może również powodować ciężką HTG poprzez hamowanie aktywności LPL. Z kolei mutacje prowadzące do utraty funkcji apoC3 są związane z korzystnym profilem lipidowym z niskim stężeniem TG [98]. Jest prawdopodobne, że ApoCIII będzie nowym celem terapii.

\section{Triglicerydemia nie na czczo (non fasting triglycerides)}

We wspólnym oświadczeniu EAS i EFLM z 2016 roku [37], profil lipidowy nie na czczo (oznaczany w próbce krwi pobieranej losowo, niezależnie od czasu od ostatniego posiłku) zalecono jako nowy standard pomiaru lipidów. Profil lipidowy na czczo (oznaczany w próbce krwi pobieranej
8-14 h od ostatniego posiłku) należy oznaczać tylko w szczególnych sytuacjach. Także w innych wytycznych zaleca się rutynowe testowanie lipidów nie na czczo [8, 51-53]. W zaleceniach EAS/EFLM podwyższone stężenia TG nie na czczo zdefiniowano jako co najmniej $2 \mathrm{mmol} / \mathrm{I}$ ( $\geq 175 \mathrm{mg} / \mathrm{dl}$ ). Gdy stężenia TG nie na czczo wynoszą ponad $5 \mathrm{mmol} / \mathrm{l}$ (442 mg/dl), zaleca się powtórzenie oznaczeń na czczo. Punkt odcięcia TG nie na czczo wynoszący $2 \mathrm{mmol} / \mathrm{I}$ (175 mg/dl) zatwierdzono prospektywnie jako punkt odcięcia, który wykazywał najlepszą czułość i swoistość w przewidywaniu zdarzeń CV [99].

\section{Triglicerydemia poposiłkowa (postprandial lipemia)}

Ocena poposiłkowej triglicerydemii (po spożyciu wysokotłuszczowego posiłku w OFTT z późniejszym pobieraniem krwi w określonym punkcie czasowym) w praktyce klinicznej jest obecnie ograniczona. Brakuje dobrze ugruntowanych i klinicznie przydatnych podstaw tego badania. W poprzednich stanowiskach, opartych na metaanalizach badań opublikowanych przed 2011 rokiem, wskazywano już, że osoby ze stężeniem TG na czczo między 1 a 2 mmol/l (89-175 mg/dl) odniosą korzyść diagnostyczną po zastosowaniu OFTT $[8,50]$ - korespondowało to ze stężeniami TG nie na czczo 1,3-2,3 mmol/I (115-200 mg/dl).

Podstawą tych zaleceń były obserwacje prawidłowej odpowiedzi na OFTT u osób ze stężeniem TG na czczo poniżej $1 \mathrm{mmol} / \mathrm{l}$ (89 mg/dl). Z kolei u osób ze stężeniem TG na czczo powyżej $2 \mathrm{mmol} / \mathrm{l}(175 \mathrm{mg} / \mathrm{dl}$ ) i ponad 2,3 mmol/l (200 mg/dl) odpowiedź TG na OFTT najczęściej jest nieprawidłowa. Rozszerzono więc zalecenie tak, by obejmowało wartości TG nie na czczo 1,3-2,3 mmol/l (115-200 mg/dl), ponieważ w wielu przypadkach próbki krwi są pobierane raczej nie na czczo, rzadziej na czczo. Po 4 godzinach od posiłku stężenia TG są zwykle o 0,3 mmol/I wyższe niż na czczo [37, 100]. Przyszłość może pokazać, czy wartości TG nie na czczo na poziomie 1,3-2,3 mmol/l (115-200 mg/dl) 
mogą być bardziej lub równie odpowiednie, co wartości TG na czczo 1-2 mmol/l (89-175 mg/dL) w OFTT.

Badania przeprowadzone $u$ hiszpańskich pacjentów z CHD (badanie CORDIOPREV) [101] i zdrowych dorosłych Amerykanów (badanie GOLDN) [102] uzasadniły definicję kliniczną poposiłkowej HTG. Nieprawidłową odpowiedź w OFTT zdefiniowano (zgodnie z poprzednim konsensusem) jako stężenie poposiłkowych TG powyżej 2,5 mmol// (> $220 \mathrm{mg} / \mathrm{dl}$ ) w dowolnym momencie po posiłku tłuszczowym. Dotyczyło to $49 \%$ chorych na CHD w badaniu CORDIOPREV i 42\% pacjentów w Stanach Zjednoczonych w badaniu GOLDN [102]. W związku z tym pacjentów w obu badaniach podzielono według stężeń TG na czczo na trzy grupy, przyjmując jako punkty odcięcia $1 \mathrm{mmol} / \mathrm{l}(89 \mathrm{mg} / \mathrm{dl})$ i $2 \mathrm{mmol} / \mathrm{I}(175 \mathrm{mg} / \mathrm{dl})$. W obu badaniach, CORDIOPREV i GOLDN, wykazano, że OFTT był najbardziej użyteczny w identyfikacji poposiłkowej HTG u osób ze stężeniem TG na czczo między 1 a 2 mmol/l (89-175 mg/dl) [103].

\section{Doustny test tolerancji tłuszczów}

Doustny test tolerancji tłuszczów wykorzystuje się głównie do badań służących dalszemu wyjaśnieniu roli TG w odniesieniu do ryzyka ASCVD. W rutynowej praktyce lekarskiej zainteresowanie testem w przypadkach indywidualnych jest coraz większe w profilaktyce i monitorowaniu terapii pacjentów z dyslipidemią [76]. Szczególnie ważne znaczenie ma to dla osób obciążonych wysokim i bardzo wysokim ryzykiem CV.

We wspomnianych badaniach CORDIOPREV i GOLDN, obejmujących ponad 2000 pacjentów, potwierdzono wartości predykcyjne zgłoszone w poprzednich wytycznych [77]. Także obecnie w zaleceniach [2] podkreślono, że stężenia TG nie na czczo powyżej 2,3 mmol/l (200 mg/dl) należy uznać za nieprawidłowe. Test tolerancji tłuszczu można wykonać przy stężeniach TG nie na czczo 1,3-2,3 mmol// (115-200 mg/dl) lub stężeniach TG na czczo 1-2 mmol/l (89-175 mg/dl). Zdefiniowana nieprawidłowa odpowiedź w OFTT to wzrost stężenia TG ponad $2,5 \mathrm{mmol} / \mathrm{l}(220 \mathrm{mg} / \mathrm{dl})$ w dowolnym czasie po posiłku [2, 99, 103-105].

W opublikowanych badaniach wartość energetyczna posiłków testowych wahała się od 345 do $1480 \mathrm{kcal}$ (głównie 700-1010 kcal), zawartość tłuszczu od 20 do 75 g (głównie 40-75 g), zawartość węglowodanów od 3 do 100 g (głównie 35-90 g), a zawartość białka od 2 do 60 g (głównie 10-30 g) [102, 106-109]. Stężenia TG na czczo wydają się głównym czynnikiem wpływającym na wartość TG po posiłku [101, 107].

Zaleca się, by posiłek stosowany w OFTT zawierał $75 \mathrm{~g}$ tłuszczu, 25 g węglowodanów i 10 g białka [2]. Obecnie produkowane są standaryzowane testy spełniające powyższe wymagania (w Polsce dostępny jest LipidTest Control). Standaryzowany test tolerancji tłuszczu powinien się składać z pojedynczego posiłku testowego dostarczającego około 75 g tłuszczu spożytego po 8 godzinach nieprzyjmowania pokarmów i pojedynczego pomiaru TG 4 godziny po posiłku (uproszczony 1-pkt. protokół może być przydatny w badaniach w dużych grupach osób i do badań klinicznych).

Czynnikiem modyfikującym lipemię poposiłkową jest wysiłek fizyczny, jakkolwiek wpływ wysiłku wygasa, gdy pobranie krwi następuje 48 godzin od ostatnich ćwiczeń [105]. Ponadto codzienna dieta i inne czynniki, takie jak wiek, płeć, wskaźnik masy ciała (BMI, body mass index), skład ciała, pochodzenie etniczne i spożycie alkoholu w ciągu 36 godzin przed testem, mogą wpłynąć na odpowiedź TG na posiłek testowy. Nadmierne spożywanie alkoholu może powodować HTG, a jeśli alkohol jest przyjmowany z posiłkiem testowym, to może prowadzić do wzrostu odpowiedzi TG po posiłku [8]. Co więcej, obniżenie wartości TG wywołane wysiłkiem jest mniej widoczne, jeśli do posiłku OFTT dodaje się alkohol [110]. Zaleca się powstrzymanie się od ćwiczeń fizycznych (ćwiczeń o większej intensywności) i spożywania alkoholu przez 20 , a nawet 48 godzin przed przeprowadzeniem OFTT.

W tabeli 2, jako podsumowaniu, zawarto zalecenia dotyczące OFTT zawarte w rekomendacjach Expert Panel Statement 2019 [2]: postprandial hypertriglyceridaemia revisited in the era of non-fasting lipid profile testing (zalecenia 1-8), uzupełnione o zalecenie 9 dotyczące grupy pacjentów, którzy powinni odnieść największą korzyść diagnostyczno-terapeutyczną z przeprowadzenia OFTT.

\section{Hipertriglicerydemia jako czynnik ryzyka ASCVD w przebiegu innych chorób}

\section{Cukrzyca typu 2 i zespół metaboliczny}

Cholesterol lipoprotein o małej gęstości jest głównym celem terapii obniżającej stężenie lipidów u pacjentów z DM i zespołem metabolicznym. W badaniach przeprowadzonych u osób z T2DM konsekwentnie wykazano znaczące korzyści terapii statynami w przypadku zdarzeń CVD u osób z T2DM [1]. Zgodnie z wytycznymi ESC/EAS z 2019 roku dyslipidemię aterogenną uznaje się za jeden z głównych czynników ryzyka CV u chorych na T2DM, u osób z otyłością brzuszną i insulinoopornością lub zaburzoną tolerancją glukozy. Dyslipidemię reprezentuje grupa nieprawidłowości lipidowych i lipoproteinowych, w tym podwyższenie zarówno stężenia TG na czczo, jak i po posiłku, wartości ApoB i obecność sdLDL oraz niskie stężenia HDL-C i ApoA1. Wartości nie-HDL-C lub ApoB są dobrymi markerami obecności lipoprotein bogatych w TG oraz remnantów i pozostają drugorzędnym celem terapii. Stężenia nie-HDL-C poniżej 2,6 mmol/l (< $100 \mathrm{mg} / \mathrm{dl}$ ) i ApoB poniżej $80 \mathrm{mg} / \mathrm{dl} \mathrm{są} \mathrm{zale-}$ cane u osób z grupy wysokiego ryzyka, a stężenia nie-HDL-C mniejsze niż 2,2 mmol/l (< $85 \mathrm{mg} / \mathrm{dl}$ ) i ApoB mniejsze niż $65 \mathrm{mg} / \mathrm{dl}$ - u osób obciążonych bardzo wysokim ryzykiem CV. W przypadku osób z grupy bardzo wysokiego ryzyka 
Tabela 2. Zalecenia dotyczące przeprowadzenia doustnego testu tolerancji tłuszczów (OFTT, oral fat tolerance test) (źródło [2])

Pożądanymi punktami odcięcia dla przeprowadzenia OFTT są stężenia TG na czczo $<2 \mathrm{mmol} / \mathrm{l}(175 \mathrm{mg} / \mathrm{dl}) \mathrm{i}<2,3 \mathrm{mmol} / \mathrm{l}$ (200 mg/dl) u osób z rozpoznaniem współistniejących chorób metabolicznych

Stężenia TG nie na czczo > 2,3 mmol/l ( $200 \mathrm{mg} / \mathrm{dl})$ należy uznać za nieprawidłowe i nie wymagają OFTT. Test ten jest wskazany u osób ze stężeniem TG nie na czczo 1,3-2,3 mmol/l (115-200 mg/dl) lub stężeniem TG na czczo 1-2 mmol/L (89-175 mg/dl). Nieprawidłową odpowiedź w OFTT zdefiniowano jako stężenie TG po 4 godzinach po posiłku > 2,5 mmol/l (220 mg/dl)

Pomiar TG po posiłku po 4 godzinach po posiłku OFTT wydaje się najlepszą metodą oceny poposiłkowej HTG u pacjentów z DM. Jednak potrzeba więcej danych, aby zdefiniować odpowiedni skład posiłku w OFTT

Pomiar TG po posiłku 4 godziny po OFTT wydaje się być najlepszą metodą oceny HTG poposiłkowej u pacjentów z zespołem metabolicznym. Jednak potrzeba więcej danych, aby zdefiniować odpowiedni skład posiłku w OFTT

Ocena poposiłkowej HTG u pacjentów z NAFLD może być przydatne w praktyce klinicznej w celu lepszej oceny ryzyka sercowo-naczyniowego i umożliwienia dokładniejszego monitorowania skuteczności środków związanych ze stylem życia i interwencji lekowych. Należy ustalić, czy kontrolowanie poposiłkowej HTG będzie korzystne dla chorych z NAFLD/bezalkoholowym stłuszczeniowym zapaleniem wątroby

Przed wykonaniem OFTT zalecana jest abstynencja od ćwiczeń fizycznych (ćwiczeń o większej intensywności) przez $20 \mathrm{~h}$ lub nawet $48 \mathrm{~h}$

Standaryzowany OFTT powinien składać się z jednego posiłku testowego zawierającego około $75 \mathrm{~g}$ tłuszczu, spożytego po 8 godzinach niejedzenia i pojedynczego pomiaru TG po 4 godzinach po posiłku (uproszczony 1-punktowy protokół może być przydatny do badań na dużych grupach osób oraz do badań klinicznych)

Zastosowanie OFTT u dzieci wymaga dalszych badań i powinno być doradzane wyłącznie indywidualnie

Przeprowadzenie OFTT jest zalecane u osób z bardzo dużym ryzykiem sercowo-naczyniowym, szczególnie po przebytym incydencie sercowo-naczyniowym na tle miażdżycy (zawale serca, udarze mózgu, ostrym niedokrwieniu naczyń obwodowych)

TG (triglycerides) - triglicerydy; HTG (hypertriglyceridemia) - hipertriglicerydemia; DM (diabetes mellitus) - cukrzyca; NAFLD (nonalcoholic fatty liver disease) - niealkoholowa stluszczeniowa choroba watroby

z nawracającymi zdarzeniami CV na tle miażdżycy można rozważyć docelowe stężenie nie-HDL-C poniżej 1,8 mmol/I $(<70 \mathrm{mg} / \mathrm{dl}$ ) i stężenie ApoB poniżej $55 \mathrm{mg} / \mathrm{dll}[1,99,100]$.

Ze względu na wielokierunkowe działanie modyfikacja stylu życia stanowi pierwszoplanowy plan działania u osób z dyslipidemią aterogenną. Utrata nadmiernej masy ciała jest w większości przypadków najskuteczniejszym środkiem, ponieważ wiąże się z bardzo wyraźnym wpływem na stężenia TG i HDL w osoczu, wraz z niewielkim obniżeniem stężeń TC i LDL. Ćwiczenia aerobowe stopnia umiarkowanego do ciężkiego również wiążą się z poprawą profilu lipidów w osoczu poprzez obniżenie stężeń TG i zwiększenie stężenia HDL-C. W odniesieniu do składu diety, oprócz konieczności wyeliminowania tłuszczów trans, dostępne dowody przemawiają za potrzebą zmniejszenia spożycia tłuszczów nasyconych i ich zastąpienia tłuszczami nienasyconymi, a także zastąpienia znacznej części rafinowanej żywności skrobiowej i cukrów prostych żywnością bogatą w błonnik, taką jak owoce, warzywa i produkty pełnoziarniste $[2,46,99,100]$.

Korzyści kliniczne uzyskane dzięki poprawie profilu lipidów obserwowane w przypadku DM, są nadal przedmiotem dyskusji, ponieważ wpływ terapii fenofibratem na główny wynik pozostawał ujemny zarówno w badaniach FIELD, jak i ACCORD przeprowadzonych w kohortach z T2DM [68-70, 72]. Chociaż z analiz post hoc wynika, że pacjenci z rozpoznaniem T2DM mogli odnieść korzyść z leczenia fibratem w połączeniu ze statyną [1].

\section{Przewlekła choroba nerek}

Przewlekła choroba nerek stanowi jeden z wiodacych problemów społecznych z wciąż wzrastającym rozpowszechnieniem sięgającym 11-13\% [111]. Według definicji Kidney Disease Outcomes Quality Initiative (K/DOQI) CKD definiuje się jako morfologiczne lub czynnościowe uszkodzenie nerek lub obniżenie przesączania kłębuszkowego poniżej $60 \mathrm{~m}^{3} / \mathrm{min} / 1,72 \mathrm{~m}^{2}$ trwające minimum 3 miesiące. Wszystkich pacjentów z CKD - zarówno leczonych zachowawczo (stadia I-IV), jak i nerkozastępczo (dializa lub przeszczepienie nerki) - cechuje wyższe niż w populacji ogólnej ryzyko rozwoju powikłań CV. Na ryzyko to wpływają tradycyjne czynniki ryzyka (wiek, płeć męska, DM, otyłość, nadciśnienie tętnicze i hiperlipidemia), jak i te zależne od CKD (dyslipidemia, zaburzenia mineralizacji kości związane z CKD [CKD-MBD, chronic kidney disease-mineral and bone disorders], stres oksydacyjny, niedożywienie i przewlekły stan zapalny). Pacjenci z CKD leczeni zachowawczo bez zespołu nerczycowego mają niskie stężenie HDL, wysokie stężenie TG oraz prawidłowe bądź niskie stężenia TC oraz LDL. Ponadto stwierdza się u nich wzrost stężeń apoB, Lp(a), lipoprotein o pośredniej gęstości (IDL, intermediate-density lipoproteins) i VLDL, cząstek resztkowych i LDL. Daje to w rezultacie wysoce aterogenny profil lipidowy. U pacjentów z zespołem nerczycowym profil ten jest jeszcze bardziej miażdżycorodny, ze zwiększonymi stężeniami TC oraz LDL. Towarzyszy mu oczywiście wysokie stężenie TG spowodowane głównie ich upośledzoną degradacją. 
Chorych na CKD poddawanych leczeniu nerkozastępczemu hemodializą charakteryzuje podobny profil lipidowy, co niedializowanych pacjentów z CKD: stężenia TC oraz LDL są zwykle prawidłowe, stężenia TG i LDL - zwiększone, a HDL - obniżone. To sprawia, że około 50\% osób ze schyłkową niewydolnością nerek umiera z powodów CV. U pacjentów leczonych metodą dializy otrzewnowej zaburzenia lipidowe są jeszcze bardziej nasilone; zwiększone są stężenia TG, VLDL i IDL, TC i LDL, a stężenie HDL jest niskie. Profil lipidowy pacjentów po transplantacji nerki obejmuje zwiększone stężenia TC, LDL, VLDL i TG oraz obniżone stężenie HDL. W tej grupie chorych najczęstszą jest tak zwana śmierć z czynnym graftem. Zgon następuje głównie z przyczyn CV [112].

\section{Niealkoholowa stłuszczeniowa choroba wątroby}

Niealkoholowa stłuszczeniowa choroba wątroby (NAFLD, non-alcoholic fatty liver disease) jest obecnie najczęstszą przewlekłą chorobą wątroby w praktyce lekarza rodzinnego, stanowiąc około $25 \%$ wszystkich schorzeń wątrobowych. W tym szerokim pojęciu mieszczą się proste stłuszczenie wątroby (NAFL, non-alcoholic fatty liver), niealkoholowe tłuszczowe zapalenie wątroby (NASH, non-alcoholic steatohepatitis), włóknienie wątroby oraz marskość. Nadal nie ma jasności, czy NASH, stosunkowo rzadka jednostka chorobowa (3\% przypadków NAFLD), która jest stłuszczeniem wątroby z towarzyszącym zapaleniem i innymi cechami uszkodzenia wątroby, prowadzącymi do nasilonego włóknienia i w konsekwencji do marskości wątroby, jest agresywną postacią NAFL, czy też jest to odmienna patogenetycznie choroba, niekoniecznie związana z klasycznymi czynnikami ryzyka NAFLD [113]. Niewątpliwie jednak towarzystwa naukowe na świecie (European Association for the Study of the Liver, American Association for the Study of Liver Disease, National Institute for Health and Care Excellence i in.) są zgodne co do tego, że chorzy z NAFL wymagają badań przesiewowych w kierunku włóknienia wątroby [114].

Niealkoholowa stłuszczeniowa choroba wątroby ma związek z otyłością, insulinoopornością, T2DM, nadciśnieniem tętniczym, hiperlipidemią i zespołem metabolicznym.

Nadwaga i otyłość potroiły swoje wskaźniki od lat 70. ubiegłego wieku. Szacuje się, że ponad 1,9 mld dorosłych ludzi na świecie (39\% populacji) żyje z nadwagą, spośród których $650 \mathrm{mln}$ to osoby otyłe (13\% populacji). Równie alarmująca sytuacja dotyczy dzieci, w tym tych poniżej 5 . roku życia (wg szacunków Światowej Organizacji Zdrowia [WHO, World Health Organization] $41 \mathrm{mln}$ dzieci w tej grupie wiekowej cierpi na otyłość) [115]. Więcej osób na świecie umrze z powodu nadwagi aniżeli z niedożywienia. Wiadomo, że przy BMI ponad $27,5 \mathrm{~kg} / \mathrm{m}^{2}$ wzrasta ryzyko powikłań zdrowotnych związanych z otyłością, takich jak incydenty CV, bezdech senny czy stłuszczenie wątroby. Zachorowalność na NAFLD wzrasta liniowo wraz z rosnącym BMI, stężeniami
TG i LDL-C, choć czasami spotyka się stłuszczenie wątroby, a zwłaszcza NASH, u osób szczupłych z hiperlipidemią. Równolegle ze wzrostem rozpowszechnienia otyłości wzrasta na świecie zapadalność na T2DM. Cukrzyca typu 2 jest ściśle powiązana z otyłością, a w NAFLD ma znaczenie podwójne. Po pierwsze 60\% osób z T2DM wykazuje cechy NAFLD, a po drugie współistnienie T2DM powoduje akcelerację procesu włóknienia wątrobowego w NAFLD, a więc jest czynnikiem ryzyka zaawansowanego włóknienia i marskości wątroby [116]. Do powikłań cukrzycy, obok nefropatii, retinopatii, angiopatii i neuropatii, można zatem śmiało zaliczyć marskość wątroby.

Wątroba jest głównym organem regulującym metabolizm kwasów tłuszczowych, w które jest zaopatrywana z różnych źródeł. W stanie głodu wątrobę zasilają wolne kwasy tłuszczowe (FFA, free fatty acids) pochodzące z lipolizy, która zachodzi w tkance tłuszczowej. W okresie jedzenia dostępne są dwie główne formy pokarmowych kwasów tłuszczowych. W formie zestryfikowanej kwasy tłuszczowe są dostarczane do wątroby z jelit w postaci bogatych w TG remnantów chylomikronowych, a jako FFA „przepływają" z tkanek obwodowych, głównie tkanki tłuszczowej, uwalniane z TG chylomikronowych przez LPL. Ponadto zachodzi wątrobowa de novo lipogeneza z prekursorów nielipidowych. Krążące FFA mogą w pewnych warunkach, na przykład w przypadku insulinooporności, stać się cytotoksyczne, dlatego w NAFLD, cechującej się podwyższonym stężeniem FFA we krwi, dochodzi do uszkodzenia komórek wątrobowych, nacieków zapalnych, nasilonej apoptozy i stymulacji produkcji kolagenu przez komórki zapalne [117]. Badanie poposiłkowej triglicerydemii ma znaczenie w NAFLD, ponieważ koreluje ona ze stężeniem przyjmowanych nasyconych kwasów tłuszczowych. Ustalono ponadto, że poposiłkowa HTG koreluje ze stopniem stłuszczenia hepatocytów. Poposiłkowa HTG, poprzez wzrost stężenia lipoprotein resztkowych, oraz nadmiar FFA biorą udział w tworzeniu blaszki miażdżycowej [118]. Zgodnie z konsensusem EAS oraz EFLM nie zachodzi konieczność wykonywania badania profilu lipidowego na czczo [37]. Jedynym parametrem lipidowym, którego stężenie poposiłkowe istotnie się różni od stężenia na czczo, są TG. Ponieważ pacjent może się znajdować w różnych fazach lipemii poposiłkowej zależnie od tego, jak dawno i w jakim składzie spożył ostatni posiłek, to bardzo wartościowym narzędziem diagnostycznym jest OFTT z wykorzystaniem standaryzowanego posiłku tłuszczowego o znanej zawartości tłuszczów, węglowodanów i białka [2].

Badanie HTG poposiłkowej w NAFLD powinno obejmować pacjentów ze zdiagnozowaną NAFLD na podstawie następujących kryteriów: 1) wynik badania USG (,jasna” wątroba); 2) podwyższona aktywność enzymów wątrobowych (przez $\geq 12$ miesięcy lub w 3 kolejnych badaniach laboratoryjnych); 3) wykluczenie spożywania istotnych ilości alkoholu (<20 g/d. w przypadku mężczyzn i $<10 \mathrm{~g} / \mathrm{d}$. 
w przypadku kobiet); 4) wykluczenie współistnienia innych przewlekłych chorób wątroby, takich jak przewlekłe wirusowe zapalenie wątroby, hemochromatoza, choroba Wilsona, autoimmunologiczne zapalenie wątroby, autoimmunologiczne choroby dróg żółciowych (pierwotne zapalenie dróg żółciowych [PBC, primary biliary cholangitis], pierwotne stwardniające zapalenie dróg żółciowych [PSC, primary sclerosing cholangitis]), celiakia; 5) potwierdzenie istotnego stłuszczenia wątroby metodą elastograficzną (FibroScan ${ }^{\circledR}$ z tzw. przystawką CAP [controled attenuated parameter], CAP > $256 \mathrm{db} / \mathrm{m}$ lub na podstawie wyniku gruboigłowej biopsji wątroby (> 5\% stłuszczonych hepatocytów).

Doustny test tolerancji tłuszczów, powtarzany co 3 miesiące do czasu uzyskania pożądanego efektu leczniczego, może służyć jako kontrola skuteczności leczenia dietetycznego i/lub farmakologicznego. U pacjentów z rozpoznaniem NAFLD co 3 miesiące należy przeprowadzić kontrolne pomiary rutynowych parametrów wątrobowych (aminotransferaza alaninowa [ALT, alanine aminotransferase], aminotransferaza asparaginianowa [ALT, aspartate aminotransferase], fosfataza alkaliczna [ALP, alkaline phosphatase], gammaglutamylopeptydaza [GGTP, gamma-glutamyl transpeptidase], bilirubina związana, morfologia z rozmazem, stężenie albumin, czas protrombinowy/ /międzynarodowy współczynnik znormalizowany [PT/INR, prothrombin time/international normalised ratio]) oraz pomiar BMI. Co 6 miesięcy pacjenta powinno się poddać badaniu metodą FibroScan ${ }^{\circledR}$ z przystawką CAP w celu oceny stłuszczenia wątrobowego.

Obecnie brakuje danych, czy strategia, polegająca na kontrolowaniu triglicerydemii poposiłkowej, wpłynie korzystnie na przebieg samej NAFLD [8]. W schorzeniu tym najlepszym postępowaniem pozostają zmniejszenie masy ciała i aktywność fizyczna.

\section{Dyslipidemia w przewlekłym zakażeniu HCV - stan po leczeniu bezpośrednio działającymi doustnymi lekami anty-HCV}

Przewlekłe zakażenie HCV cechuje się istotnym stłuszczeniem wątroby i zaburzeniami metabolicznymi. Dokładne mechanizmy związku zakażenia wirusem zapalenia wątroby typu C (HCV, hepatitis C virus) ze stłuszczeniem wątroby nie są poznane. Wydaje się, że HCV interferuje z procesem łączenia TG i apoB za pośrednictwem mikrosomalnego białka przenoszącego triglicerydy (MTTP, microsomal triglyceride transfer protein). W transgenicznym mysim modelu wykazano, że HCV hamuje aktywność MTTP w wątrobie. Ponadto HCV może stymulować syntezę cholesterolu i kwasów tłuszczowych poprzez oddziaływanie na ważne regulatory lipogenezy - SREBP 1c i 2 (steroid responsive element binding proteins). Hamowanie syntezy cholesterolu przez statyny wpływa hamująco na replikację HCV. Składanie potomnych wirionów HCV rozpoczyna się w hepatocytach na powierzchni małych organelli komórkowych (LD, lipid droplets), magazynujących lipidy. Aby sobie umożliwić opuszczenie zakażonej komórki, HCV „przechwytuje” lipoproteiny gospodarza i wykorzystuje szlaki transportu lipidów poza komórkę hepatocyta do własnych celów. Poza komórkę wątrobową wydostają się kompleksy będące połączeniem cząstek wirusa z lipoproteinami w lipowirocząsteczki o małej gęstości. Takie połączenie umożliwia wirusowi skuteczny atak na nowe komórki, ponieważ wejście do hepatocyta odbywa się poprzez receptor dla LDL [119]. Wiadomo na pewno, że zakażenie HCV pogarsza przebieg T2DM u predysponowanych osób, a w niektórych przypadkach współistnieją objawy zespołu metabolicznego.

Nie jest do końca jasne, czy zespół metaboliczny i HCV są ze sobą powiązane patogenetycznie, ale na pewno na siebie wzajemnie oddziałują. „Wirusowy” charakter stłuszczenia wątroby potwierdzono w zakażeniu genotypem 3 HCV. W przypadku innych genotypów HCV, zwłaszcza najpowszechniej występującego genotypu 1b, wirusowy charakter stłuszczenia hepatocytów nie jest już tak oczywisty. Niektórzy badacze sugerują przypadkowe współistnienie dwóch częstych stanów chorobowych - zakażenia HCV i zaburzeń metabolicznych wynikających z nadmiernej podaży kalorii, nadwagi lub otyłości [120].

Za akumulację tłuszczów w wątrobie osoby zakażonej HCV odpowiada kilka mechanizmów. W wyniku wymienionych wyżej zaburzeń dochodzi do akumulacji lipidów w komórce wątrobowej i stłuszczenia wątroby, natomiast we krwi obwodowej stwierdza się zazwyczaj hipolipidemię [119].

Wydaje się oczywiste, że po wyleczeniu z zakażenia HCV (SVR, sustained viral response) za pomocą leków o bezpośrednim działaniu przeciwwirusowym (DAA, direct acting antivirals) powinno dojść do poprawy kontroli glikemii, zmniejszenia stłuszczenia w wątrobie i wzrostu stężenia lipidów we krwi obwodowej [121]. Wstępne doniesienia o zjawiskach metabolicznych po wyleczeniu z HCV są intrygujące. Bez wątpienia poprawie ulega metabolizm glukozy i zmniejsza się insulinooporność, ale jednocześnie zauważono, że często dochodzi do niewielkiego wzrostu masy ciała, zwłaszcza u kobiet, a u osób, które nie miały stłuszczenia wątroby albo stłuszczenie było niewielkie, dochodzi do wzrostu wartości CAP po eradykacji HCV [122]. Zauważono też wzrost stężeń VLDL-C i LDL-C we krwi. To ostatnie zjawisko jest zapewne związane z wydostawaniem się lipidów z komórek wątrobowych po „odhamowaniu” MTTP i uwolnieniu szlaków transportowych zajmowanych dotychczas przez cząsteczki wirusowe [123, 124]. Dość niepokojące są doniesienia o stwierdzeniu pogrubienia przydanki tętnic szyjnych rok po osiągnięciu SVR, co może się wiązać ze wzrostem CV w wyniku leczenia przeciwwirusowego. Doniesienie to wymaga potwierdzenia w większej grupie chorych [125]. 
Jak wiadomo, LDL-C odgrywa kluczową rolę w rozwoju i progresji miażdżycy, co prowadzi do powikłań CV. Na LDL składa się kilka frakcji, w tym sdLDL (small dense $L D L$ ) o szczególnie dużym potencjale aterogennym, ponieważ ze względu na rozmiar łatwo przechodzą do blaszki miażdżycowej i tam więzną. Do tej pory nie badano sdLDL w kontekście klirensu HCV po udanym leczeniu przeciwwirusowym. Wzrost stężenia sdLDL obserwuje się na przykład w NAFLD, ale nie wiadomo, czy po wyleczeniu z zakażenia HCV ten wzrost podlega podobnym mechanizmom, na przykład czy zależy od wrażliwości na insulinę. Otyłość centralna z HTG jest związana z wysoką aktywnością LPL prowadzącą do powstawania proaterogennych sdLDL. Wirus zapalenia wątroby typu C hamuje produkcję wątrobowej lipazy TG, co skutkuje wzrostem stężenia LDL bogatych w TG. Po eliminacji HCV powinno nastąpić odwrócenie tego zjawiska. Wymaga to dalszych badań.

Być może, wyleczenie z zakażenia HCV prowadzi do pogorszenia stylu życia, powrotu do niewłaściwej diety, a nawet spożywania alkoholu. Dlatego pojawiają się zwiększenie masy ciała i zjawiska metaboliczne zbliżone do NAFLD. Poposiłkowa HTG może się nakładać na wzmożony napływ lipoprotein pochodzenia wątrobowego. Czy badanie lipemii poposiłkowej okaże się przydatne w kontroli zaburzeń metabolicznych po wyleczeniu z HCV? By to ustalić, niezbędne są dalsze badania.

\section{Opis przeprowadzenia OFTT w praktyce}

Obecnie w Polsce przeprowadza się OFTT w odniesieniu do triglicerydemii na czczo. Test ten można przeprowadzić u osób ze stężeniem TG na czczo między 89 a 175 mg/dl (1-2 mmol/l). Uzasadnieniem takiego zakresu TG jako kryterium włączenia do OFTT są wyniki dużych badań klinicznych, na podstawie których przyjęto, że u osób ze stężeniem TG na czczo poniżej $89 \mathrm{mg} / \mathrm{dl}$ lipemia poposiłkowa jest prawidłowa, natomiast u osób ze stężeniem TG na czczo powyżej $175 \mathrm{mg} / \mathrm{dl}$ wzrost stężenia TG po posiłku pozostaje nieprawidłowo wysoki; w jednym i drugim przypadku pacjenci nie odniosą więc korzyści z przeprowadzenia OFTT.

Prawidłowe przeprowadzenie OFTT wymaga następującej współpracy z badanym:

- przez 24 godziny przed wykonaniem testu pacjenta obowiązuje zakaz spożywania alkoholu i intensywnego wysiłku fizycznego;

- po 10-12 godzinach nieprzyjmowania pokarmów przez pacjenta pobiera się pierwszą próbkę krwi;

- oznacza się stężenie TG na czczo;

- wynik stężenia TG na czczo 89-175 mg/dl dopuszcza pacjenta do obciążenia posiłkiem testowym, np. Lipid-Test Control;

- pacjent spożywa posiłek testowy w ciągu 5 minut;
- przez 4 godziny po spożyciu posiłku badany powinien unikać wysiłku fizycznego. Zabronione jest spożywanie dodatkowych posiłków i picie wszelkich słodzonych napojów, dozwolone jest jedynie picie wody;

- po 4 godzinach pobiera się kolejną próbkę krwi i mierzy stężenie poposiłkowych TG.

Za prawidłowe stężenie TG $\mathrm{w}$ badaniu poposiłkowym uważa się wartość do $220 \mathrm{mg} / \mathrm{dl}(2,25 \mathrm{mmol} / \mathrm{l})$. Stężenie między 221 a 499 mg/dl (2,26-5,63 mmol/l) jest diagnozowane jako wysokie, ale niewymagające wdrożenia leczenia farmakologicznego, wymaga natomiast leczenia dietetycznego i przeprowadzenia kontrolnego OFTT po 3 miesiącach. Stężenie TG poposiłkowych powyżej $499 \mathrm{mg} / \mathrm{dl}$ (5,63 mmol/l) to wartość bardzo wysoka - wymaga leczenia farmakologicznego oraz diagnostyki przyczyny.

Po spożyciu posiłku testowego mogą wystąpić objawy niepożądane, takie jak nudności, wymioty, biegunka, zaparcia, bóle brzucha, zazwyczaj o miernym nasileniu, ogólne złe samopoczucie i osłabienie.

Wskazania względne do przeprowadzenia OFTT to: profilaktyczne badanie profilu lipidowego u wszystkich mężczyzn powyżej 35. roku życia i kobiet powyżej 45. roku, nieprawidłowe stężenie TG w badaniu na czczo i nie na czczo, zdiagnozowana miażdżyca, T2DM, insulinooporność, nadciśnienie tętnicze, choroba wieńcowa, nadwaga $\left(B M I>27 \mathrm{~kg} / \mathrm{m}^{2}\right.$ ) i otyłość, brak ruchu, palenie tytoniu, menopauza, obciążający wywiad rodzinny w kierunku przedwczesnej ASCVD.

\section{Podsumowanie}

Oznaczanie triglicerydemii poposiłkowej jest narzędziem diagnostycznym do identyfikacji osób, które mogą gromadzić bogate w TG resztkowe lipoproteiny po posiłku. Należą do nich pacjenci z rodzinnymi postaciami złożonej HTG, dysbetalipoproteinemii typu III i HTG związaną z DM i zespołem metabolicznym. Jak dotąd, w żadnym modelu terapeutycznym leczenia zaburzeń lipidowych nie uwzględniono oceny HTG poposiłkowej. Według panelu ekspertów z 2019 roku [99, 100] i według polskich ekspertów wykorzystujących w praktyce klinicznej OFTT ocena HTG poposiłkowej po standardowym OFTT może być wartościowa u osób ze stężeniem TG na czczo 1-2 mmol/l (89-175 mg/dl) oraz u osób ze stężeniem TG nie na czczo 1,3-2,3 mmol/I (115-200 mg/dl). Wymaga to jednak dalszej oceny. Pozostaje wiele pytań, na przykład dotyczących interpretacji ryzyka CV u pacjentów z nieprawidłową lipemią poposiłkową, oraz znalezienie odpowiedzi na pytanie, czy nieprawidłowa HTG poposiłkowa powinna być wykorzystywana jako cel terapeutyczny [100].

Eksperci widzą, jednak duży potencjał naukowo-diagnostyczny w szerszym upowszechnieniu wystandaryzowanej oceny HTG poposiłkowej. Wydaje się, że w przyszłości test ten zajmie podobną rolę $w$ lipidologii, jak obecne badanie 
tolerancji glukozy w diabetologii. Analogii między oboma tymi badaniami jest zresztą wiele. Oprócz wielu grup pacjentów wymienionych w niniejszym dokumencie warte rozpowszechnienia wydaje się zastosowanie tej procedury w pierwszym rzędzie:

- u pacjentów z cukrzycą/zespołem metabolicznym, u których wykonane badania TG na czczo nie było wskazaniem do rozpoznania i/lub podjęcia leczenia HTG;
- u pacjentów z chorobą miażdżycową lub jej ekwiwalentem epidemiologicznym, zainteresowanych bardziej pełną oceną swojego profilu metabolicznego;

- u innych osób, których choroby przewlekłe lub wczesna prewencja tych chorób wymagają monitorowania i zachowania: normotonii, normoglikemii i normolipemii w celu bardziej optymalnego zdefiniowania tej ostatniej składowej prawidłowego zdrowia.

\section{Abstract}

The following paper presents positions of experts from various, mainly European scientific societies regarding utility of postprandial hypertriglyceridemia (HTG) in predicting cardiovascular (CV) risk. New studies and different categories of patients have been included. The following text has been based mainly on 2019 European Society of Cardiology and European Atherosclerosis Society guidelines regarding the management of dyslipidemia, as well as the 2019 international expert panel document. The position of Polish experts on using oral fat tolerance test in clinical practice has also been presented. Remaining problem is to assess potential usefulness of postprandial HTG in estimation of CV risk and to determine whether performing the oral fat tolerance test, that involves consumption of a standard high-fat preparation followed by blood collection at indicated time intervals, can improve CV risk assessment. Although importance of postprandial HTG in the assessment of atherogenic risk is increasingly well documented, there is still need for further research.

Key words: hypertriglyceridemia, cardiovascular risk, oral fat tolerance test (OFTT)

Folia Cardiologica 2020; 15, supl. A: A1-A17

\section{Piśmiennictwo}

1. Mach F, Baigent C, Catapano AL, et al. ESC Scientific Document Group. 2019 ESC/EAS Guidelines for the management of dyslipidaemias: lipid modification to reduce cardiovascular risk. Eur Heart J. 2020; 41(1): 111-188, doi: 10.1093/eurheartj/ehz455, indexed in Pubmed: 31504418.

2. Kolovou GD, Watts GF, Mikhailidis DP, et al. Postprandial hypertriglyceridaemia revisited in the era of non-fasting lipid profile testing: a 2019 Expert Panel Statement, main text. Curr Vasc Pharmacol. 2019; 17(5): 498-514, doi: 10.2174/1570161117666190507110519, indexed in Pubmed: 31060488.

3. Mihaylova B, Emberson J, Blackwell L, et al. Cholesterol Treatment Trialists' (CTT) Collaborators. The effects of lowering LDL cholesterol with statin therapy in people at low risk of vascular disease: meta-analysis of individual data from 27 randomised trials. Lancet. 2012; 380(9841): 581-590, doi: 10.1016/S0140-6736(12)60367-5, indexed in Pubmed: 22607822.

4. Navarese EP, Robinson JG, Kowalewski M, et al. Association between baseline LDL-C level and total and cardiovascular mortality after LDL-C lowering: a systematic review and meta-analysis. JAMA. 2018; 319(15): 1566-1579, doi: 10.1001/jama.2018.2525, indexed in Pubmed: 29677301.

5. Boekholdt SM, Hovingh GK, Mora S, et al. Very low levels of atherogenic lipoproteins and the risk for cardiovascular events: a meta-analysis of statin trials. J Am Coll Cardiol. 2014; 64(5): 485-494, doi: 10.1016/j.jacc.2014.02.615, indexed in Pubmed: 25082583.
6. Stone NJ, Robinson JG, Lichtenstein AH, et al. American College of Cardiology/American Heart Association Task Force on Practice Guidelines. 2013 ACC/AHA Guideline on the treatment of blood cholesterol to reduce atherosclerotic cardiovascular risk in adults: a report of the American College of Cardiology/American Heart Association Task Force on Practice Guidelines. J Am Coll Cardiol. 2014; 63(25 Pt B): 2889-2934, doi: 10.1016/j.jacc.2013.11.002, indexed in Pubmed: 24239923.

7. National Institute for Health and Care Excellence (NICE). Clinical guideline CG181: lipid modification - cardiovascular risk assessment and the modification of blood lipids for the primary and secondary prevention of cardiovascular disease. National Clinical Guideline Centre 2014. https://www.nice.org.uk/guidance/cg181 (3.12.2019).

8. Anderson TJ, Grégoire J, Pearson GJ, et al. 2016 Canadian Cardiovascular Society Guidelines for the Management of Dyslipidemia for the Prevention of Cardiovascular Disease in the Adult. Can J Cardiol. 2016; 32(11): 1263-1282, doi: 10.1016/j.cjca.2016.07.510, indexed in Pubmed: 27712954.

9. Bibbins-Domingo K, Grossman DC, Curry SJ, et al. US Preventive Services Task Force. Statin use for the primary prevention of cardiovascular disease in adults: US Preventive Services Task Force Recommendation Statement. JAMA. 2016; 316(19): 1997-2007, doi: 10.1001/ /jama.2016.15450, indexed in Pubmed: 27838723.

10. Piepoli MF, Hoes AW, Agewall S, et al. Authors/Task Force Members:, Authors/Task Force Members, Additional Contributor: Simone Binno (Italy), Document Reviewers:, ESC Scientific Document Group. 2016 
European Guidelines on cardiovascular disease prevention in clinical practice: The Sixth Joint Task Force of the European Society of Cardiology and Other Societies on Cardiovascular Disease Prevention in Clinical Practice (constituted by representatives of 10 societies and by invited experts)Developed with the special contribution of the European Association for Cardiovascular Prevention \& Rehabilitation (EACPR). Eur Heart J. 2016; 37(29): 2315-2381, doi: 10.1093/eurheartj/ehw106, indexed in Pubmed: 27222591.

11. Baigent C, Blackwell L, Emberson J, et al. Cholesterol Treatment Trialists' (CTT) Collaboration. Efficacy and safety of more intensive lowering of LDL cholesterol: a meta-analysis of data from 170,000 participants in 26 randomised trials. Lancet. 2010; 376(9753): 1670-1681, doi: 10.1016/S0140-6736(10)61350-5, indexed in Pubmed: 21067804.

12. Hsia J, MacFadyen JG, Monyak J, et al. Cardiovascular event reduction and adverse events among subjects attaining low-density lipoprotein cholesterol $<50 \mathrm{mg} /$ dl with rosuvastatin. The JUPITER trial (Justification for the Use of Statins in Prevention: an Intervention Trial Evaluating Rosuvastatin). J Am Coll Cardiol. 2011; 57(16): 1666-1675, doi: 10.1016/j.jacc.2010.09.082, indexed in Pubmed: 21492764.

13. McCormack T, Dent R, Blagden M. Very low LDL-C levels may safely provide additional clinical cardiovascular benefit: the evidence to date. Int J Clin Pract. 2016; 70(11): 886-897, doi: 10.1111/ijcp.12881, indexed in Pubmed: 27739167.

14. Sabatine MS, Giugliano RP, Keech AC, et al. FOURIER Steering Committee and Investigators. Evolocumab and clinical outcomes in patients with cardiovascular disease. N Engl J Med. 2017; 376(18): 1713-1722, doi: 10.1056/NEJMoa1615664, indexed in Pubmed: 28304224.

15. Ray KK, Colhoun HM, Szarek M, et al. ODYSSEY OUTCOMES Committees and Investigators, ODYSSEY OUTCOMES Committees and Investigators, ODYSSEY OUTCOMES Committees and Investigators. Alirocumab and cardiovascular outcomes after acute coronary syndrome. N Engl J Med. 2018; 379(22): 2097-2107, doi: 10.1056/ /NEJMoa1801174, indexed in Pubmed: 30403574.

16. Cannon CP, Blazing MA, Giugliano RP, et al. IMPROVE-IT Investigators. Ezetimibe added to statin therapy after acute coronary syndromes. N Engl J Med. 2015; 372(25): 2387-2397, doi: 10.1056/ /NEJMoa1410489, indexed in Pubmed: 26039521.

17. Ridker PM, Revkin J, Amarenco P, et al. SPIRE Cardiovascular Outcome Investigators. Cardiovascular efficacy and safety of bococizumab in high-risk patients. N Engl J Med. 2017; 376(16): 1527-1539, doi: 10.1056/NEJMoa1701488, indexed in Pubmed: 28304242.

18. Bowman L, Hopewell JC, Chen F, et al. HPS3/TIMI55-REVEAL Collaborative Group. Effects of anacetrapib in patients with atherosclerotic vascular disease. N Engl J Med. 2017; 377(13): 1217-1227, doi: 10.1056/NEJMoa1706444, indexed in Pubmed: 28847206.

19. Ridker PM, Everett BM, Thuren T, et al. CANTOS Trial Group. Antiinflammatory therapy with canakinumab for atherosclerotic disease. N Engl J Med. 2017; 377(12): 1119-1131, doi: 10.1056/NEJMoa1707914, indexed in Pubmed: 28845751.

20. Kolovou GD, Mikhailidis DP, Kovar J, et al. Assessment and clinical relevance of non-fasting and postprandial triglycerides: an expert panel statement. Curr Vasc Pharmacol. 2011; 9(3): 258-270, doi: 10.2174/157016111795495549, indexed in Pubmed: 21314632.

21. Chapman MJ, Ginsberg HN, Amarenco P, et al. European Atherosclerosis Society Consensus Panel. Triglyceride-rich lipoproteins and high-density lipoprotein cholesterol in patients at high risk of cardiovas- cular disease: evidence and guidance for management. Eur Heart J. 2011; 32(11): 1345-1361, doi: 10.1093/eurheartj/ehr112, indexed in Pubmed: 21531743.

22. Nordestgaard BG, Varbo A. Triglycerides and cardiovascular disease. Lancet. 2014; 384(9943): 626-635, doi: 10.1016/s01406736(14)61177-6, indexed in Pubmed: 25131982.

23. Nordestgaard BG. Triglyceride-rich lipoproteins and atherosclerotic cardiovascular disease: new insights from epidemiology, genetics, and biology. Circ Res. 2016; 118(4): 547-563, doi: 10.1161/ /CIRCRESAHA.115.306249, indexed in Pubmed: 26892957.

24. Klempfner R, Erez A, Sagit BZ, et al. Elevated triglyceride level is independently associated with increased all-cause mortality in patients with established coronary heart disease: twenty-two-year follow-up of the bezafibrate infarction prevention study and registry. Circ Cardiovasc Qual Outcomes. 2016; 9(2): 100-108, doi: 10.1161/CIRCOUTCOMES.115.002104, indexed in Pubmed: 26957517.

25. Mora S, Wenger NK, Demicco DA, et al. Determinants of residual risk in secondary prevention patients treated with high- versus low-dose statin therapy: the Treating to New Targets (TNT) study. Circulation. 2012; 125(16): 1979-1987, doi: 10.1161/CIRCULATIONAHA.111.088591, indexed in Pubmed: 22461416.

26. Vallejo-Vaz AJ, Fayyad R, Boekholdt SM, et al. Triglyceride-rich lipoprotein cholesterol and risk of cardiovascular events among patients receiving statin therapy in the TNT trial. Circulation. 2018; 138(8): 770-781, doi: 10.1161/CIRCULATIONAHA.117.032318, indexed in Pubmed: 29618599.

27. Faergeman 0, Holme I, Fayyad R, et al. Steering Committees of IDE$\mathrm{AL}$ and TNT Trials. Plasma triglycerides and cardiovascular events in the Treating to New Targets and Incremental Decrease in End-Points through Aggressive Lipid Lowering trials of statins in patients with coronary artery disease. Am J Cardiol. 2009; 104(4): 459-463, doi: 10.1016/j.amjcard.2009.04.008, indexed in Pubmed: 19660594.

28. Lawler PR, Akinkuolie AO, Chu AY, et al. Atherogenic lipoprotein determinants of cardiovascular disease and residual risk among individuals with low low-density lipoprotein cholesterol. J Am Heart Assoc. 2017; 6(7), doi: 10.1161/JAHA.117.005549, indexed in Pubmed: 28733430.

29. Nordestgaard BG, Benn M, Schnohr P, et al. Nonfasting triglycerides and risk of myocardial infarction, ischemic heart disease, and death in men and women. JAMA. 2007; 298(3): 299-308, doi: 10.1001/ /jama.298.3.299, indexed in Pubmed: 17635890.

30. Varbo A, Benn M, Nordestgaard BG, et al. Remnant cholesterol as a causal risk factor for ischemic heart disease. J Am Coll Cardiol. 2013; 61(4): 427-436, doi: 10.1016/j.jacc.2012.08.1026, indexed in Pubmed: 23265341.

31. Varbo A, Benn M, Tybjærg-Hansen A, et al. Elevated remnant cholesterol causes both low-grade inflammation and ischemic heart disease, whereas elevated low-density lipoprotein cholesterol causes ischemic heart disease without inflammation. Circulation. 2013; 128(12): 1298-1309, doi: 10.1161/CIRCULATIONAHA.113.003008, indexed in Pubmed: 23926208.

32. Helgadottir A, Gretarsdottir S, Thorleifsson G, et al. Variants with large effects on blood lipids and the role of cholesterol and triglycerides in coronary disease. Nat Genet. 2016; 48(6): 634-639, doi: 10.1038/ /ng.3561, indexed in Pubmed: 27135400.

33. Varbo A, Benn M, Smith GD, et al. Remnant cholesterol, low-density lipoprotein cholesterol, and blood pressure as mediators from obesity to ischemic heart disease. Circ Res. 2015; 116(4): 
665-673, doi: 10.1161/CIRCRESAHA.116.304846, indexed in Pubmed: 25411050.

34. Jørgensen AB, Frikke-Schmidt R, West AS, et al. Genetically elevated non-fasting triglycerides and calculated remnant cholesterol as causal risk factors for myocardial infarction. Eur Heart J. 2013; 34(24): 1826-1833, doi: 10.1093/eurheartj/ehs431, indexed in Pubmed: 23248205.

35. Jepsen AMK, Langsted A, Varbo A, et al. Increased remnant cholesterol explains part of residual risk of all-cause mortality in 5414 patients with ischemic heart disease. Clin Chem. 2016; 62(4): 593-604, doi: 10.1373/clinchem.2015.253757, indexed in Pubmed: 26888894.

36. Varbo A, Freiberg JJ, Nordestgaard BG. Remnant cholesterol and myocardial infarction in normal weight, overweight, and obese individuals from the Copenhagen General Population Study. Clin Chem. 2018; 64(1): 219-230, doi: 10.1373/clinchem.2017.279463, indexed in Pubmed: 29021326.

37. Nordestgaard BG, Langsted A, Mora S, et al. Fasting is not routinely required for determination of a lipid profile: clinical and laboratory implications including flagging at desirable concentration cut-points. A joint consensus statement from the EAS and EFLM. Eur Heart J. 2016; 37(25): 1944-1958, doi: 10.1093/eurheartj/ehw152, indexed in Pubmed: 27122601.

38. Di Angelantonio E, Gao P, Pennells L, et al. Emerging Risk Factors Collaboration. Lipid-related markers and cardiovascular disease prediction. JAMA. 2012; 307(23): 2499-2506, doi: 10.1001/ /jama.2012.6571, indexed in Pubmed: 22797450.

39. Silverman MG, Ference BA, Im K, et al. Association between lowering LDL-C and cardiovascular risk reduction among different therapeutic interventions: a systematic review and meta-analysis. JAMA. 2016; 316(12): 1289-1297, doi: 10.1001/jama.2016.13985, indexed in Pubmed: 27673306.

40. Sarwar N, Sandhu MS, Ricketts SL, et al. Triglyceride Coronary Disease Genetics Consortium and Emerging Risk Factors Collaboration. Triglyceride-mediated pathways and coronary disease: collaborative analysis of 101 studies. Lancet. 2010; 375(9726): 1634-1639, doi: 10.1016/S0140-6736(10)60545-4, indexed in Pubmed: 20452521.

41. Lewis GF, Xiao C, Hegele RA. Hypertriglyceridemia in the genomic era: a new paradigm. Endocr Rev. 2015; 36(1): 131-147, doi: 10.1210/ /er.2014-1062, indexed in Pubmed: 25554923.

42. Dron JS, Hegele RA. Complexity of mechanisms among human proprotein convertase subtilisin-kexin type 9 variants. Curr Opin Lipidol. 2017; 28(2): 161-169, doi: 10.1097/MOL.0000000000000386, indexed in Pubmed: 28157721.

43. Ference BA, Kastelein JJP, Ray KK, et al. Association of triglyceride-lowering LPL variants and LDL-C-lowering LDLR variants with risk of coronary heart disease. JAMA. 2019; 321(4): 364-373, doi: 10.1001/ /jama.2018.20045, indexed in Pubmed: 30694319.

44. Rifai N, Warnick GR. Lipids, lipoproteins, apolipoproteins, and other cardiovascular risk factors. In: Burtis CA, Ashwood ER, Bruns DE. ed. Tietz textbook of clinical chemistry and molecular diagnostics. Elsevier Saunders, Philadelphia 2006: 903-982.

45. Simundic AM, Cornes M, Grankvist K, et al. Standardization of collection requirements for fasting samples: for the Working Group on Preanalytical Phase (WG-PA) of the European Federation of Clinical Chemistry and Laboratory Medicine (EFLM). Clin Chim Acta. 2014; 432: 33 -37, doi: 10.1016/j.cca.2013.11.008, indexed in Pubmed: 24269503.
46. Kolovou GD, Anagnostopoulou KK, Salpea KD, et al. The prevalence of metabolic syndrome in various populations. Am J Med Sci. 2007; 333(6): 362-371, doi: 10.1097/MAJ.0b013e318065c3a1, indexed in Pubmed: 17570989.

47. Nordestgaard B. A test in context: lipid profile, fasting versus nonfasting. Journal of the American College of Cardiology. 2017; 70(13): 1637-1646, doi: 10.1016/j.jacc.2017.08.006.

48. Pikto Pietkiewicz I, Boden WE, Probstfield JL, et al. AIM-HIGH Investigators. Niacin in patients with low HDL cholesterol levels receiving intensive statin therapy. N Engl J Med. 2011; 365(24): 2255-2267, doi: 10.1056/NEJMoa1107579, indexed in Pubmed: 22085343.

49. Freiberg JJ, Tybjaerg-Hansen A, Jensen JS, et al. Nonfasting triglycerides and risk of ischemic stroke in the general population. JAMA. 2008; 300(18): 2142-2152, doi: 10.1001/jama.2008.621, indexed in Pubmed: 19001625.

50. Catapano AL, Graham I, De Backer G, et al. Additional Contributor, Authors/Task Force Members:, ESC Scientific Document Group. 2016 ESC/EAS Guidelines for the management of dyslipidaemias. Eur Heart J. 2016; 37(39): 2999-3058, doi: 10.1093/eurheartj/ehw272, indexed in Pubmed: 27567407.

51. Leung AA, Nerenberg K, Daskalopoulou SS, et al. CHEP Guidelines Task Force. Hypertension Canada's 2016 Canadian Hypertension Education Program Guidelines for Blood Pressure Measurement, Diagnosis, Assessment of Risk, Prevention, and Treatment of $\mathrm{Hy}$ pertension. Can J Cardiol. 2016; 32(5): 569-588, doi: 10.1016/ /j.cjca.2016.02.066, indexed in Pubmed: 27118291.

52. Scartezini M, Ferreira CE, Izar MC, et al. Positioning about the flexibility of fasting for lipid profiling. Arq Bras Cardiol. 2017; 108(3): 195 -197, doi: 10.5935/abc.20170039, indexed in Pubmed: 28443960.

53. Miller M, Stone NJ, Ballantyne C, et al. American Heart Association Clinical Lipidology, Thrombosis, and Prevention Committee of the Council on Nutrition, Physical Activity, and Metabolism, Council on Arteriosclerosis, Thrombosis and Vascular Biology, Council on Cardiovascular Nursing, Council on the Kidney in Cardiovascular Disease. Triglycerides and cardiovascular disease: a scientific statement from the American Heart Association. Circulation. 2011; 123(20): $2292-$ -2333, doi: 10.1161/CIR.0b013e3182160726, indexed in Pubmed: 21502576 .

54. Ooi EMM, Watts GF, Ng TWK, et al. Effect of dietary Fatty acids on human lipoprotein metabolism: a comprehensive update. $\mathrm{Nu}$ trients. 2015; 7(6): 4416-4425, doi: 10.3390/nu7064416, indexed in Pubmed: 26043038.

55. Borén J, Matikainen N, Adiels M, et al. Postprandial hypertriglyceridemia as a coronary risk factor. Clin Chim Acta. 2014; 431: 131-142, doi: 10.1016/j.cca.2014.01.015, indexed in Pubmed: 24508990.

56. Kolovou GD, Mikhailidis DP, Nordestgaard BG, et al. Definition of postprandial lipaemia. Curr Vasc Pharmacol. 2011; 9(3): 292-301, do i: 10.2174/157016111795495611, indexed in Pubmed: 21314628.

57. Boekholdt SM, Hovingh GK, Mora S, et al. Association of LDL cholesterol, non-HDL cholesterol, and apolipoprotein B levels with risk of cardiovascular events among patients treated with statins: a meta-analysis. JAMA. 2012; 307(12): 1302-1309, doi: 10.1001/ /jama.2012.366, indexed in Pubmed: 22453571.

58. Shaikh M, Wootton R, Nordestgaard BG, et al. Quantitative studies of transfer in vivo of low density, Sf 12-60, and Sf 60-400 lipoproteins between plasma and arterial intima in humans. Arterioscler Thromb. 1991; 11(3): 569-577, doi: 10.1161/01.atv.11.3.569, indexed in Pubmed: 2029497. 
59. Nordestgaard BG, Tybjaerg-Hansen A, Lewis B. Influx in vivo of low density, intermediate density, and very low density lipoproteins into aortic intimas of genetically hyperlipidemic rabbits. Roles of plasma concentrations, extent of aortic lesion, and lipoprotein particle size as determinants. Arterioscler Thromb. 1992; 12(1): 6-18, doi: 10.1161/01.atv.12.1.6, indexed in Pubmed: 1731859.

60. Nordestgaard BG, Wootton R, Lewis B. Selective retention of VLDL, $I D L$, and LDL in the arterial intima of genetically hyperlipidemic rabbits in vivo. Molecular size as a determinant of fractional loss from the intima-inner media. Arterioscler Thromb Vasc Biol. 1995; 15(4): 534-542, doi: 10.1161/01.atv.15.4.534, indexed in Pubmed: 7749867.

61. Toth PP. Triglyceride-rich lipoproteins as a causal factor for cardiovascular disease. Vasc Health Risk Manag. 2016; 12: 171-183, doi: 10.2147/VHRM.S104369, indexed in Pubmed: 27226718.

62. Dallinga-Thie GM, Kroon J, Borén J, et al. Triglyceride-rich lipoproteins and remnants: targets fortherapy? Curr Cardiol Rep. 2016; 18(7): 67 , doi: 10.1007/s11886-016-0745-6, indexed in Pubmed: 27216847.

63. Rosenson RS, Helenowski IB, Tangney CC. Heterogeneous postprandial lipoprotein responses in the metabolic syndrome, and response to fenofibrate therapy. Cardiovasc Drugs Ther. 2010; 24(5-6): 439-447, doi: 10.1007/s10557-010-6264-6, indexed in Pubmed: 20922563.

64. Pavlidis AN, Kolovou GD, Anagnostopoulou KK, et al. Postprandial metabolic heterogeneity in men with primary dyslipidaemia. Arch Med Sci. 2010; 6(6): 879-886, doi: 10.5114/aoms.2010.19295, indexed in Pubmed: 22427761.

65. Kolovou GD, Anagnostopoulou KK, Pavlidis AN, et al. Metabolic syndrome and gender differences in postprandial lipaemia. Eur J Cardiovasc Prev Rehabil. 2006; 13(4): 661-664, doi: 10.1097/01. hjr.0000224490.10845.26, indexed in Pubmed: 16874161.

66. Bansal S, Buring JE, Rifai N, et al. Fasting compared with nonfasting triglycerides and risk of cardiovascular events in women. JAMA. 2007; 298(3): 309-316, doi: 10.1001/jama.298.3.309, indexed in Pubmed: 17635891.

67. Lindman AS, Veierød MB, Tverdal A, et al. Nonfasting triglycerides and risk of cardiovascular death in men and women from the Norwegian Counties Study. Eur J Epidemiol. 2010; 25(11): 789-798, doi: 10.1007/s10654-010-9501-1, indexed in Pubmed: 20890636.

68. Keech A, Simes RJ, Barter P, et al. FIELD study investigators. Effects of long-term fenofibrate therapy on cardiovascular events in 9795 people with type 2 diabetes mellitus (the FIELD study): randomised controlled trial. Lancet. 2005; 366(9500): 1849-1861, doi: 10.1016/ /S0140-6736(05)67667-2, indexed in Pubmed: 16310551.

69. Reyes-Soffer G, Ngai Cl, Lovato L, et al. Effect of combination therapy with fenofibrate and simvastatin on postprandial lipemia in the ACCORD lipid trial. Diabetes Care. 2013; 36(2): 422-428, doi: 10.2337/dc11-2556, indexed in Pubmed: 23033246.

70. Elam MB, Ginsberg HN, Lovato LC, et al. ACCORDION Study Investigators. Association of fenofibrate therapy with long-term cardiovascular risk in statin-treated patients with type 2 diabetes. JAMA Cardiol. 2017; 2(4): 370-380, doi: 10.1001/jamacardio.2016.4828, indexed in Pubmed: 28030716.

71. ACCORD Study Group. Nine-year effects of 3.7 years of intensive glycemic control on cardiovascular outcomes. Diabetes Care. 2016; 39(5): 701-708, doi: 10.2337/dc15-2283, indexed in Pubmed: 26822326.

72. Scott R, O'Brien R, Fulcher G, et al. Fenofibrate Intervention and Event Lowering in Diabetes (FIELD) Study Investigators. Effects of fenofibrate treatment on cardiovascular disease risk in 9,795 individuals with type 2 diabetes and various components of the metabolic syndrome: the Fenofibrate Intervention and Event Lowering in Diabetes (FIELD) study. Diabetes Care. 2009; 32(3): 493-498, doi: 10.2337/dc081543, indexed in Pubmed: 18984774.

73. Bezafibrate Infarction Prevention (BIP) study. Secondary prevention by raising HDL cholesterol and reducing triglycerides in patients with coronary artery disease. Circulation. 2000; 102(1): 21-27, doi: 10.1161/01.cir.102.1.21, indexed in Pubmed: 10880410.

74. Rubins H, Robins S, Collins D, et al. Gemfibrozil for the secondary prevention of coronary heart disease in men with low levels of high-density lipoprotein cholesterol. N Engl J Med. 1999; 341(6): 410-418, doi: 10.1056/nejm199908053410604, indexed in Pubmed: 10438259.

75. Manninen V, Elo MO, Frick MH, et al. Lipid alterations and decline in the incidence of coronary heart disease in the Helsinki Heart Study. JAMA. 1988; 260(5): 641-651, indexed in Pubmed: 3164788.

76. Mihas C, Kolovou GD, Mikhailidis DP, et al. Diagnostic value of postprandial triglyceride testing in healthy subjects: a meta-analysis. Curr Vasc Pharmacol. 2011; 9(3): 271-280, doi: 10.2174/15701611 1795495530, indexed in Pubmed: 21314631.

77. Perez-Martinez P, Alcala-Diaz JF, Kabagambe EK, et al. Assessment of postprandial triglycerides in clinical practice: Validation in a general population and coronary heart disease patients. J Clin Lipidol. 2016; 10(5): 1163-1171, doi: 10.1016/j.jacl.2016.05.009, indexed in Pubmed: 27678433.

78. Niederwanger A, Ciardi C, Tatarczyk T, et al. Postprandial lipemia induces pancreatic $\alpha$ cell dysfunction characteristic of type 2 diabetes: studies in healthy subjects, mouse pancreatic islets, and cultured pancreatic $\alpha$ cells. Am J Clin Nutr. 2014; 100(5): 1222-1231, doi: 10.3945/ajcn.114.092023, indexed in Pubmed: 25332320.

79. Mattes RD. Brief oral stimulation, but especially oral fat exposure, elevates serum triglycerides in humans. Am J Physiol Gastrointest Liver Physiol. 2009; 296(2): G365-G371, doi: 10.1152/ /ajpgi.90591.2008, indexed in Pubmed: 19074638.

80. Schneeman BO, Kotite L, Todd KM, et al. Relationships between the responses of triglyceride-rich lipoproteins in blood plasma containing apolipoproteins B-48 and B-100 to a fat-containing meal in normolipidemic humans. Proc Natl Acad Sci USA. 1993; 90(5): 2069-2073, doi: 10.1073/pnas.90.5.2069, indexed in Pubmed: 8446630.

81. Cohn JS, Johnson EJ, Millar JS, et al. Contribution of apoB-48 and apoB-100 triglyceride-rich lipoproteins (TRL) to postprandial increases in the plasma concentration of TRL triglycerides and retinyl esters. J Lipid Res. 1993; 34(12): 2033-2040, indexed in Pubmed: 8301224.

82. Adiels M, Taskinen MR, Packard C, et al. Overproduction of large VLDL particles is driven by increased liver fat content in man. Diabetologia. 2006; 49(4): 755-765, doi: 10.1007/s00125-005-0125-z, indexed in Pubmed: 16463046.

83. Timlin MT, Parks EJ. Temporal pattern of de novo lipogenesis in the postprandial state in healthy men. Am J Clin Nutr. 2005; 81(1): 35-42, doi: 10.1093/ajcn/81.1.35, indexed in Pubmed: 15640457.

84. Matikainen N, Adiels M, Söderlund S, et al. Hepatic lipogenesis and a marker of hepatic lipid oxidation, predict postprandial responses of triglyceride-rich lipoproteins. Obesity (Silver Spring). 2014; 22(8): 1854-1859, doi: 10.1002/oby.20781, indexed in Pubmed: 24890344.

85. Berglund L, Brunzell JD, Goldberg AC, et al. Endocrine society. EvaIuation and treatment of hypertriglyceridemia: an Endocrine Society clinical practice guideline. J Clin Endocrinol Metab. 2012; 97(9): 2969-2989, doi: 10.1210/jc.2011-3213, indexed in Pubmed: 22962670. 
86. Downs JR, O'Malley PG. Management of dyslipidemia for cardiovascular disease risk reduction: synopsis of the 2014 U.S. Department of Veterans Affairs and U.S. Department of Defense clinical practice guideline. Ann Intern Med. 2015; 163(4): 291-297, doi: 10.7326/ /M15-0840, indexed in Pubmed: 26099117.

87. Jacobson TA, Maki KC, Orringer CE, et al. NLA Expert Panel. National Lipid Association Recommendations for Patient-Centered Management of Dyslipidemia: Part 2. J Clin Lipidol. 2015; 9(6 Suppl): S1-122. e1, doi: 10.1016/j.jacl.2015.09.002, indexed in Pubmed: 26699442.

88. Jellinger PS, Handelsman Y, Rosenblit P, et al. American association of clinical endocrinologists and american college of endocrinology guidelines for management of dyslipidemia and prevention of cardiovascular disease. Endocr Pract. 2017; 23(Suppl2): 1-87, doi: 10.4158/ /ep171764.appgl.

89. Grundy SM, Stone NJ, Bailey AL, et al. 2018 AHA/ACC/AACVPR/ /AAPA/ ABC/ACPM/ADA/AGS/APhA/ASP C/NLA/PCNA guideline on the management of blood cholesterol: executive summary: a report of the American College of cardiology/American Heart association task force on clinical practice guidelines. J Am Coll Cardiol. 2018; pii: S0735-1097(18)39033-8.

90. Bhatt DL, Steg PG, Miller M, et al. REDUCE-IT Investigators. Cardiovascular risk reduction with icosapent ethyl for hypertriglyceridemia. N EngI J Med. 2019; 380(1): 11-22, doi: 10.1056/NEJMoa1812792, indexed in Pubmed: 30415628.

91. Chapman MJ, Redfern JS, McGovern ME, et al. Niacin and fibrates in atherogenic dyslipidemia: pharmacotherapy to reduce cardiovascular risk. Pharmacol Ther. 2010; 126(3): 314-345, doi: 10.1016/j. pharmthera.2010.01.008, indexed in Pubmed: 20153365.

92. The ACCORD Study Group. Effects of combination lipid therapy in type 2 diabetes mellitus. N Engl J Med. 2010; 362(17): 1563-1574, doi: 10.1056/nejmoa1001282.

93. Keech A, Simes RJ, Barter P, et al., FIELD study investigators. Effects of long-term fenofibrate therapy on cardiovascular events in 9795 people with type 2 diabetes mellitus (the FIELD study): randomised controlled trial. The Lancet. 2005; 366(9500): 1849-1861, doi: 10.1016/s0140-6736(05)67667-2.

94. Catapano AL, Farnier M, Foody JM, et al. Combination therapy in dyslipidemia: where are we now? Atherosclerosis. 2014; 237(1): 319-335, doi: 10.1016/j.atherosclerosis.2014.09.026, indexed in Pubmed: 25299967.

95. Brahm AJ, Hegele RA. Chylomicronaemia - current diagnosis and future therapies. Nat Rev Endocrinol. 2015; 11(6): 352-362, doi: 10.1038/nrendo.2015.26, indexed in Pubmed: 25732519.

96. Bauer RC, Khetarpal SA, Hand NJ, et al. Therapeutic targets of triglyceride metabolism as informed by human genetics. Trends Mol Med. 2016; 22(4): 328-340, doi: 10.1016/j.molmed.2016.02.005, indexed in Pubmed: 26988439.

97. Gaudet D, Méthot J, Déry S, et al. Efficacy and long-term safety of alipogene tiparvovec (AAV1-LPLS447X) gene therapy for lipoprotein lipase deficiency: an open-label trial. Gene Ther. 2013; 20(4): 361-369, doi: 10.1038/gt.2012.43, indexed in Pubmed: 22717743.

98. Huff MW, Hegele RA. Apolipoprotein C-III: going back to the future for a lipid drug target. Circ Res. 2013; 112(11): 1405-1408, doi: 10.1161/ /CIRCRESAHA.113.301464, indexed in Pubmed: 23704213.

99. Kolovou GD, Watts GF, Mikhailidis DP, et al. Postprandial hypertriglyceridaemia revisited in the era of non-fasting lipid profiles: executive summary of a 2019 Expert Panel Statement. Curr Vasc Pharmacol. 2019; 17(5): 538-540, doi: 10.2174/15701611179991905171154 32, indexed in Pubmed: 31418346.
100. Kolovou GD, Watts GF, Mikhailidis DP, et al. Postprandial hypertriglyceridaemia revisited in the era of non-fasting lipid profile testing: a 2019 Expert Panel Statement, narrative review. Curr Vasc Pharmacol. 2019; 17(5): 515-537, doi: 10.2174/1570161117666190503123911, indexed in Pubmed: 31309820.

101. Alcala-Diaz JF, Delgado-Lista J, Perez-Martinez P, et al. Hypertriglyceridemia influences the degree of postprandial lipemic response in patients with metabolic syndrome and coronary artery disease: from the CORDIOPREV study. PLoS One. 2014; 9(5): e96297, doi: 10.1371/ /journal.pone.0096297, indexed in Pubmed: 24802225.

102. Wojczynski MK, Parnell LD, Pollin TI, et al. Genome-wide association study of triglyceride response to a high-fat meal among participants of the NHLBI Genetics of Lipid Lowering Drugs and Diet Network (GOLDN). Metabolism. 2015; 64(10): 1359-1371, doi: 10.1016/ /j.metabol.2015.07.001, indexed in Pubmed: 26256467.

103. Kolovou GD, Salpea KD, Anagnostopoulou KK, et al. Alcohol use, vascular disease, and lipid-lowering drugs. J Pharmacol Exp Ther. 2006; 318(1): 1-7, doi: 10.1124/jpet.106.102269, indexed in Pubmed: 16627749.

104. Ooi TC, Nordestgaard BG. Methods to study postprandial lipemia. Curr Vasc Pharmacol. 2011; 9(3): 302-308, doi: 10.2174/15701611179 5495567, indexed in Pubmed: 21314627.

105. Tsetsonis NV, Hardman AE, Mastana SS. Acute effects of exercise on postprandial lipemia: a comparative study in trained and untrained middle-aged women. Am J Clin Nutr. 1997; 65(2): 525-533, doi: 10.1093/ajcn/65.2.525, indexed in Pubmed: 9022540.

106. White KT, Moorthy MV, Akinkuolie AO, et al. Identifying an optimal cutpoint for the diagnosis of hypertriglyceridemia in the nonfasting state. Clin Chem. 2015; 61(9): 1156-1163, doi: 10.1373/clinchem.2015.241752, indexed in Pubmed: 26071491.

107. Langsted A, Freiberg JJ, Nordestgaard BG. Fasting and nonfasting lipid levels: influence of normal food intake on lipids, lipoproteins, apolipoproteins, and cardiovascular risk prediction. Circulation. 2008; 118(20): 2047-2056, doi: 10.1161/CIRCULATIONAHA.108.804146, indexed in Pubmed: 18955664.

108. Delgado-Lista J, Perez-Martinez P, Garcia-Rios A, et al. CoRonary Diet Intervention with Olive oil and cardiovascular PREVention study (the CORDIOPREV study): Rationale, methods, and baseline characteristics: A clinical trial comparing the efficacy of a Mediterranean diet rich in olive oil versus a low-fat diet on cardiovascular disease in coronary patients. Am Heart J. 2016; 177: 42-50, doi: 10.1016/ /j.ahj.2016.04.011, indexed in Pubmed: 27297848.

109. Vors C, Pineau G, Gabert L, et al. Modulating absorption and postprandial handling of dietary fatty acids by structuring fat in the meal: a randomized crossover clinical trial. Am J Clin Nutr. 2013; 97(1): 23-36, doi: 10.3945/ajcn.112.043976, indexed in Pubmed: 23235199.

110.Slivkoff-Clark KM, James AP, Mamo JCl. The chronic effects of fish oil with exercise on postprandial lipaemia and chylomicron homeostasis in insulin resistant viscerally obese men. Nutr Metab (Lond). 2012; 9: 9, doi: 10.1186/1743-7075-9-9, indexed in Pubmed: 22314022.

111. Hill NR, Fatoba ST, Oke JL, et al. Global prevalence of chronic kidney disease - a systematic review and meta-analysis. PLoS One. 2016; 11(7): e0158765, doi: 10.1371/journal.pone.0158765, indexed in Pubmed: 27383068.

112. Mikolasevic I, Žutelija M, Mavrinac V, et al. Dyslipidemia in patients with chronic kidney disease: etiology and management. Int J Nephrol Renovasc Dis. 2017; 10: 35-45, doi: 10.2147/ijnrd.s101808, indexed in Pubmed: 28223836. 
113. Younossi ZM. Non-alcoholic fatty liver disease - a global public health perspective. J Hepatol. 2019; 70(3): 531-544, doi: 10.1016/ /j.jhep.2018.10.033, indexed in Pubmed: 30414863.

114. Armstrong MJ, Marchesini G. Referral pathways for NAFLD fibrosis in primary care - no longer a 'needle in a haystack'. J Hepatol. 2019; 71(2): 246-248, doi: 10.1016/j.jhep.2019.05.010, indexed in Pubmed: 31229270.

115. NCD Risk Factor Collaboration (NCD-RisC). Worldwide trends in body-mass index, underweight, overweight, and obesity from 1975 to 2016: a pooled analysis of 2416 population-based measurement studies in 128.9 million children, adolescents, and adults. Lancet. 2017; 390(10113): 2627-2642, doi: 10.1016/S0140-6736(17)32129-3, indexed in Pubmed: 29029897.

116. Nobili V, Mantovani A, Cianfarani S, et al. Prevalence of prediabetes and diabetes in children and adolescents with biopsy-proven non-alcoholic fatty liver disease. J Hepatol. 2019; 71(4): 802-810, doi: 10.1016/j.jhep.2019.06.023, indexed in Pubmed: 31279904.

117. Gambino R, Bugianesi E, Rosso C, et al. Different serum free fatty acid profiles in NAFLD subjects and healthy controls after oral fat load. Int J Mol Sci. 2016; 17(4): 479, doi: 10.3390/ijms17040479, indexed in Pubmed: 27043543.

118. Musso G, Gambino R, De Michieli F, et al. Dietary habits and their relations to insulin resistance and postprandial lipemia in nonalcoholic steatohepatitis. Hepatology. 2003; 37(4): 909-916, doi: 10.1053/ /jhep.2003.50132, indexed in Pubmed: 12668986.

119. Lonardo A, Adinolfi LE, Loria P, et al. Steatosis and hepatitis C virus: mechanisms and significance for hepatic and extrahepatic disease.
Gastroenterology. 2004; 126(2): 586-597, doi: 10.1053/j.gastro.2003.11.020, indexed in Pubmed: 14762795.

120. White DL, Ratziu V, El-Serag HB. Hepatitis C infection and risk of diabetes: a systematic review and meta-analysis. J Hepatol. 2008; 49(5): 831-844, doi: 10.1016/j.jhep.2008.08.006, indexed in Pubmed: 18814931.

121. Serfaty L. Metabolic manifestations of hepatitis $C$ virus. Clinics in Liver Disease. 2017; 21(3): 475-486, doi: 10.1016/j.cld.2017.03.004.

122. Kawagishi N, Suda G, Nakamura A, et al. Liver steatosis and dyslipidemia after HCV eradication by direct acting antiviral agents are synergistic risks of atherosclerosis. PLoS One. 2018; 13(12): e0209615, doi: 10.1371/journal.pone.0209615, indexed in Pubmed: 30576386.

123.González-Aldaco K, Torres-Reyes LA, Ojeda-Granados C, et al. Immunometabolic effect of cholesterol in hepatitis $c$ infection: implications in clinical management and antiviral therapy. Ann Hepatol. 2018; 17(6): 908-919, doi: 10.5604/01.3001.0012.7191, indexed in Pubmed: 30600305

124. Beig J, Orr D, Harrison B, et al. Hepatitis $C$ virus eradication with new interferon-free treatment improves metabolic profile in hepatitis $\mathrm{C}$ virus-related liver transplant recipients. Liver Transpl. 2018; 24(8): 1031-1039, doi: 10.1002/It.25060, indexed in Pubmed: 29577581.

125. Ichikawa T, Miyaaki H, Miuma S, et al. Carotid intima-media thickness and small dense low-density lipoprotein cholesterol increase after one year of treatment with direct-acting antivirals in patients with hepatitis C virus infection. Intern Med. 2019; 58(9): 1209-1215, doi: 10.2169/ /internalmedicine.1514-18, indexed in Pubmed: 30626818. 
Czy ocena lipemii poposiłkowej powinna stać się standardem postępowania u chorych z dyslipidemią? Komentarz do stanowiska polskich ekspertów: Lipemia poposiłkowa - problem kliniczny i potencjalne miejsce $w$ algorytmach diagnostycznych

Should postprandial lipemia evaluation become a standard in the management of patients with dyslipidemia? Commentary to the position of Polish experts: Postprandial lipemia: a clinical problem and potential place in cardiovascular risk estimation

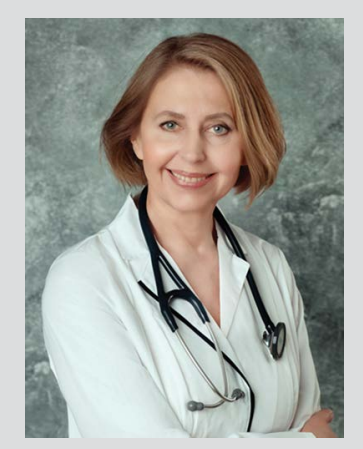

\section{Beata Wożakowska-Kapłon iD}

I Klinika Kardiologii i Elektroterapii Świętokrzyskiego Centrum Kardiologii w Kielcach Wydział Lekarski i Nauk o Zdrowiu Uniwersytetu Jana Kochanowskiego w Kielcach

Zaburzenia lipidowe są głównym elementem sprawczym rozwoju blaszki miażdżycowej i czynnikiem ryzyka epizodów sercowo-naczyniowych. 0 ile jednak nie podlegają dyskusji wyniki rejestrów populacyjnych i badań klinicznych, wyznaczające zarówno liniową zależność między stężeniem cholesterolu frakcji lipoprotein o małej gęstości (LDL-C, low-density lipoprotein cholesterol) a zachorowaniem na chorobę miażdżycową tętnic oraz ograniczeniem ryzyka zdarzeń sercowo-naczyniowych w przypadku skutecznej kontroli stężenia LDL-C, o tyle związek zawałów serca i udarów mózgu z hipertriglicerydemią i korzyści z jej ograniczenia nie są tak jednoznaczne. Oznaczenie stężenia triglicerydów (TG, triglycerides) w celu oceny ryzyka sercowo-naczyniowego, ustalenia rozpoznania oraz wyboru leczenia ma I klasę zaleceń z poziomem wiarygodności danych C [1]. W I klasie zaleceń znalazło się również obliczanie stężenia niecholesterolu frakcji lipoprotein o dużej gęstości (nie HDL-C, non-high-density lipoprotein cholesterol), zwłaszcza u osób z wysokim stężeniem TG oraz, po raz pierwszy w wytycznych dotyczących dyslipidemii w 2019 roku, oznaczanie stężenia apolipoproteiny B (ApoB) jako parametru alternatywnego w stosunku do stężenia nie-HDL-C. Oznaczanie stężenia ApoB w celu oceny ryzyka jest rekomendowane u pacjentów z wysokim stężeniem TG, cukrzycą, otyłością, zespołem metabolicznym oraz bardzo niskim stężeniem LDL-C $w$ ramach badań przesiewowych oraz w celu diagnozy i leczenia, przed oznaczaniem nie-HDL-C. Zarówno w odniesieniu do stężenia nie-HDL-C, ukazującego całkowitą liczbę aterogennych cząsteczek w osoczu, jak i w odniesieniu do ApoB autorzy aktualnych wytycznych wyznaczają precyzyjnie cele terapii dla różnych kategorii ryzyka sercowo-naczyniowego [1]. Problem pojawia się dopiero przy definiowaniu hipertriglicerydemii i wyznaczeniu celów jej terapii. Czy hipertriglicerydmią jest stężenie TG powyżej $150 \mathrm{mg} / \mathrm{dl}$, czy też powyżej $200 \mathrm{mg} / \mathrm{dl}$ ? Czy terapię hipertriglicerydemii powinno się rozpocząć wtedy, gdy stężenie TG przekracza $499 \mathrm{mg} / \mathrm{dl}, 885 \mathrm{mg} / \mathrm{dl}$, czy może $1000 \mathrm{mg} / \mathrm{dl}$ ? I czy celem terapii hipetriglicerydemii powinna jest prewencja ostrego zapalenia trzustki czy może obniżenie sercowo-naczyniowego? W przedstawionym dokumencie polscy eksperci odnoszą się do tych zagadnień w sposób wyczerpujący i precyzyjny, wskazując również nowe możliwości diagnostyczne oceny lipemii poposiłkowej odzwierciedlającej indywidualny stan metaboliczny lepiej niż profil na czczo [2]. Ten element oceny może być szczególnie przydatny w szerokiej populacji chorych na cukrzycę, z zespołem metabolicznym, przewlekłą chorobą nerek, niealkoholową stłuszczeniową chorobą wątroby czy u osób otyłych. Analogicznie do oceny reakcji na obciążenie glukozą w teście tolerancji glukozy (OGTT, oral glucoe tolerance test), hipertriglicerydemia poposiłkowa oceniana za pomoca doustnego testu tolerancji tłuszczów (OFTT, oral fat tolerance test) umożliwia precyzyjną oceny rezydualnego ryzyka chorób układu sercowo-naczyniowego na podłożu miażdżycy. Interwencja farmakologiczna celowana w wybranych grupach z nieprawidłowym wynikiem OFTT, obok obowiązkowej modyfikacji stylu życia, daje szansę na obniżenie ryzyka resztkowego u chorych, u których już osiagnnięto docelowe stężenie LDL-C. U kogo autorzy dokumentu zalecają przeprowadzenie OFTT? Są to grupy pacjentów z rozpoznaniem współistniejących chorób metabolicznych i stężeniem TG nie na czczo w zakresie 115-200 mg/dl (1,3-2,3 mm/l) lub stężeniem TG na czczo w granicach 89-175 mg/dl. U chorych, u których stężenie TG nie na czczo przekracza $200 \mathrm{mg} / \mathrm{dl}$ (> 2,3 mmol), rozpoznana jest hipertriglicerydemia i nie wymagają OFTT. Zważywszy na to, że problem nadwagi i otyłości dotyczy w Polsce $62 \%$ mężczyzn i $47 \%$ kobiet, a wśród osób powyżej 55. roku życia - 78\% mężczyzn i 75\% kobiet, a częstość występowania zaburzeń metabolizmu glukozy oraz cukrzycy występuje u 27\% mężczyzn i 19\% kobiet [3-5], OFTT może być znakomitym testem przesiewowym służącym wykrywaniu zaburzeń metabolizmu lipidów i wytypowaniu osób szczególnie podatnych na rozwój wcześniejszych zmian miażdżycowych i ich powikłań. W niedalekiej przyszłości poposiłkowa ocena profilu lipidowego prawdopodobnie znajdzie 
miejsce w algorytmach diagnostycznych szerokiej populacji pacjentów, ale już teraz stanowi cenną opcję poszerzenia indywidualnej oceny profilu lipidowego u osób z grup zwiększonego ryzyka sercowo-naczyniowego.

\section{Piśmiennictwo}

1. Ibanez B, James S, Agewall S, et al. 2017 ESC Guidelines for the management of acute myocardial infarction in patients presenting with ST-segment elevation: the Task Force for the management of acute myocardial infarction in patients presenting with ST-segment elevation of the European Society of Cardiology (ESC). Eur Heart J. 2018; 39(2): 119-177, doi: 10.1093/eurheartj/ehx393, indexed in Pubmed: 28886621.

2. Skoczyńska A, Wawrzynowicz-Syczewska M, Barlik-Rysa M, et al. Lipemia poposiłkowa - problem kliniczny i potencjalne miejsce w algorytmach diagnostycznych. Stanowisko polskich ekspertów. Folia Cardiol. 2020; 15(Suppl A): A1-A17, doi: 10.5603/FC.2020.0001.

3. Poznańska A, Rabczenko D, Wojtyniak B. Wybrane czynniki ryzyka zdrowotnego związane ze stylem życia. In: Wojtyniak B, Goryń- ski P. ed. Sytuacja zdrowotna ludności Polski i jej uwarunkowania. Narodowy Instytut Zdrowia Publicznego Państwowy Zakład Higieny, Warszawa 2016.

4. Stepaniak U, Micek A, Waśkiewicz A, et al. Prevalence of general and abdominal obesity and overweight among adults in Poland. Results of the WOBASZ II study (2013-2014) and comparison with the WOBASZ study (2003-2005). Pol Arch Med Wewn. 2016; 126(9): 662-671, doi: 10.20452/pamw.3499, indexed in Pubmed: 27535012.

5. Rutkowski M, Bandosz P, Czupryniak L, et al. Prevalence of diabetes and impaired fasting glucose in Poland - the NATPOL 2011 Study. Diabet Med. 2014; 31(12): 1568-1571, doi: 10.1111/ /dme.12542, indexed in Pubmed: 24975751. 